\title{
Treatments of Non-wood Plant Fibres Used as Reinforcement in Composite Materials
}

\author{
Marie-Ange Arsène ${ }^{\mathrm{a}}$, Ketty Bilba ${ }^{\mathrm{a}}$, Holmer Savastano Junior ${ }^{\mathrm{b}}$, Khosrow Ghavamic** \\ ${ }^{a}$ Laboratoire COVACHIM-M2E, Département de Chimie, UFR SEN, Université des Antilles et de la \\ Guyane - UAG, Campus de Fouillole, 97157 Pointe-A-Pitre, Guadeloupe \\ ${ }^{b}$ Rural Construction Group, Faculty of Animal Sciences and Food Engineering, University of \\ São Paulo-USP, CP 23, CEP 13635-900, Pirassununga, SP, Brazil \\ 'Department of Civil Engineering, Pontifical Catholic University of Rio de Janeiro - PUC-Rio, \\ CEP 22453-900, Rio de Janeiro, RJ, Brazil
}

Received: November 24, 2011; Revised: January 15, 2013

\begin{abstract}
This paper presents a summary of the knowledge on fibres and pulps of non wood tropical plants used as reinforcement in cementitious composites accumulated during the recent years by Guadeloupean and Brazilian teams participating in collaborative work. Vegetable fibres represent a good alternative as non-conventional materials for the construction of ecological and sustainable buildings. The use of such renewable resources contributes to the development of sustainable technologies. The main objective of the paper is to emphasize the use of agricultural wastes in the production of cement based composites. The botanical, chemical, physical, morphological and mechanical properties of fibres from various plants are described. The effects of different treatments on physical, chemical and mechanical properties of fibres are presented. The most effective treatments in influencing the mechanical and physical properties are pyrolysis and alkaline ones, according to the type of plant. The final choice will have to consider fibre availability, and treatment costs.
\end{abstract}

Keywords: non wood plants, vegetable fibres, pulping, chemical treatments, pyrolysis

\section{Introduction}

During last three decades, the global need for affordable housing has stimulated extensive research on cementitious matrix composites ${ }^{1-18}$. Different groups in tropical regions have conducted an important effort on the study of cementitious composite materials reinforced with vegetable fibres ${ }^{1-6,12,16}$. Indeed, vegetable fibres offer a cheap and sustainable approach that can be used to reduce the overall cost of construction materials and electricity consumption. The goal for developing such alternative technologies is to promote sustainable building materials. Brazilian and Guadeloupean research groups have accumulated important knowledge on tropical vegetable fibres. This fundamental knowledge on non wood tropical plants can be useful for numerous applications such as fibre cement, green composites, particle boards and papermaking ${ }^{5,19-24}$. The fibre reinforcement is necessary to improve mechanical properties of a given building material, which would be otherwise unsuitable for practical applications. A major advantage concerning fibre reinforcement of a brittle material (e.g., cement paste, mortar or concrete) is the composite behavior after cracking. Post-cracking toughness enhanced by fibres in the material may allow large-scale construction use of such composites ${ }^{21}$.

There are two approaches for the development of new composites. The first one is based on the production of thin flat or corrugated sheets of asbestos-free fibre cement. These components are produced by wellknown industrialscale processes such as Hatschek or other similar methods commercially used with high acceptance for building

*e-mail: ghavami@puc-rio.br purposes. The second approach consists of producing composites for different types of building components like load-bearing hollowed wall, roofing tiles and ceiling boards 22,25 .

The purpose of this paper is to present the morphological, chemical, physical and mechanical characteristics of non wood fibres from sugar cane, banana and coconut plant, arrow root and sisal. Different chemical treatments with calcium hydroxide and sulphuric acid, thermal treatment by pyrolysis, coating with silanes and pulping and their effects on physical, chemical and mechanical properties of the fibres are presented.

The paper is divided in seven sections. Following the introduction, a review of the studied fibres including plant description, chemical and morphological characterizations of vegetable fibres are presented in Section 2. The state of art on vegetable fibre treatments and the description of processes constitute Section 3. Section 4 presents the pulp and pulping process. In Section 5, the experimental procedures are described for treated vegetable fibres. The final sections bring results, discussion and conclusion on the potential applications based on fibre properties in relation to their treatments.

\section{Plant Fibres Description and Characterization}

\subsection{Plants}

Sugarcane (Saccharum officinarum) is a perennial plant originally from south valley of central Himalaya, part of the 
family Poaceas ${ }^{26}$. The herbaceous plant generally grows by bundles of few straight stalks with a cluster of leaves at the extremity. It is cultivated for its stalk to extract the sugar cane juice from which sugar is obtained by evaporation and crystallization. Rum and ethanol which is used as biofuel, are obtained by fermentation. Bagasse fibre is a by-product of this sugar cane industry, located in the tropical and subtropical regions of the world, leftover after crushing of the stalk. The bagasse/stalk ratio by mass is around $30 \%$. Bagasse makes a sugar mill more than self-sufficient in energy; the surplus bagasse can be used as animal feed, in paper manufacture, or as fibres to reinforce cement based matrix ${ }^{27}$. This last aspect of the use of sugar cane bagasse constitutes the objective of this paper.

Banana tree (Musa acuminata and Musa cavendishii) is a high herbaceous plant (2-16 m high) from Musaceas family coming from south east Asia, India and Melanesian Islands of the Pacific ${ }^{26}$. From the underground rhizome the terminal bud is the origin of the pseudo-stem made by the imbrication and overlapping of the leaves. Banana trees produce generally 30 large leaves (almost $2 \mathrm{~m}$ long and $30-60 \mathrm{~cm}$ wide). The long fibres represent approximately $1.5 \%$ by total mass of the plant and its extraction can proceed in conformity with cultivation requirements by returning the low-fibrous parts of the pseudo-stem to the plantations as organic fertilizer ${ }^{28,29}$

The coconut tree (Cocos nucifera L.) comes from south Asia. It is a very high monocotyledon $(20-30 \mathrm{~m})$ plant of Areaceas family present in tropical zones of Americas, Pacific Region and $\mathrm{Asia}^{26}$. It is a single trunk tree containing 25-26 leaves which does not produce timber. Fruits are grouped at the base of the leaves. They have a big nut surrounded by a fibrous husk or coir.

Arrow root (Maranta arundinacea) is a vegetable from South America, cultivated in Guadeloupe and Martinique, French West Indies (FWI), for the alimentation of children feeding due to its high content in vitamin A, calcium and iron. It is a tuberous rhizome tapered, of the Marantaceas family, with very long fibrous roots ${ }^{26}$.

The sisal (Agave sisalana) fibres are easily obtained from the leaves of the Agave plants. The sisal plant and its products have proved, over centuries of natural and commercial production, that they can serve mankind as a sustainable renewable resource for its cordage, woven, pharmaceutical and building products. Sisal is produced in Africa (e. g. Tanzania, Kenya and Madagascar), South America (e. g. Brazil and Venezuela) and Mexico, where it originated. Central American countries also produce small amounts of this fibre ${ }^{25}$.

In 2004 the annual production of fibre in Brazil was about 139.7 thousand tonnes, making it the largest producer of sisal in the world. The Brazilian production is concentrated in the states of Bahia (87\%) and Paraíba (7.4\%), both located in the northeast region of the country ${ }^{19,30}$. The estimated amount of waste material generated from sisal industry is about 500000 tonnes (air dried basis, $\sim 15 \%$ moisture content) a year in Brazil, mainly due to the low yield of rude mechanical extraction procedures combined with pour cultivation technologies. By the present dominant production system only $3 \%$ by mass of the original sisal leaf is transformed in commercial fibres suitable for cordage industry performing a discouraging activity ${ }^{31}$ in face of plastic fibre concurrence. As an alternative, sisal leaves are also being used by the pulp and paper industry and there are many attempts to use it in cementitious $^{12}$ and polymeric ${ }^{32,33}$ composites.

\subsection{Chemical composition}

The chemical compositions of the vegetable fibres have been studied over the past 15 years ${ }^{1,34-37}$ in the Université des Antilles et de la Guyane (UAG), in Guadeloupe (FWI). Chemical analyses of the fibres were carried out using classical methods ${ }^{34}$. Lignin content was determined using the Klason process ${ }^{34}$, after an acid exposure for $16 \mathrm{~h}$ and a complete hydrolysis to eliminate all the hemicellulose and cellulose. Cellulose content was determined by acid attack with a mixture of ethanol and nitric acid. The hemicellulose content, mainly pentosanes, was determined by indirect methods. The extractive components (tannin, pectin and wax, e. g.) were isolated by ethanol/toluene extraction ${ }^{34}$. The cellulose, hemicellulose and lignin contents reported are mean values of four to six measurements from different harvests determined from a given mass of fibre.

Hence, the summarized results are updated data with their respective standard deviations. The major botanical components and chemical elements are presented in Table 1. The sugar cane bagasse, simply called "bagasse", is the fibrous by-product left after juice extraction from the stalk to produce rum or sugar. The banana pseudo-stem is referred as "banana trunk" in this paper and was obtained from a plantation. Coconut fibres were extracted from the sheath of coconut leaves or from the fruit that is also called the coir. The sheath of young coconut leaves is found between the trunk and the leaves remaining around the trunk. Arrow root fibres are waste of flour extraction from the rhizome. For the fibres studied, the lignin content varies from 5.0 to $46.5 \%$; the cellulose content varies from 21.5 to $64.0 \%$ and the hemicellulose content from 12.4 to $32 \%$ (excepting softwood), and the extractives range from 1.7 to $9.8 \%$. These components are localized in the walls of the unitary fibres that represent 50 to $69 \%$ of the surface of the fibre.

For the same botanical species, the chemical composition varies with the location in the plant as observed by MarquezMontesino et al. ${ }^{37}$ and Ouensanga ${ }^{34}$. The contents of lignin and extractive are greater in the upper part of the plant, and the content of cellulose is higher at the bottom of the plant. This means that the content of cellulose is higher in the trunk compared to that of the leaf for banana trees and greater in the sheath compared to coir for coconut trees. For banana, the upper part is the leaf if compared to trunk, and for coconut tree, coir is the upper part compared to sheath.

The composition of the arrow root fibres reported in Table 1 has been determined previously ${ }^{2}$ using the method described by Ouensanga ${ }^{34}$.

Chemical composition (Table 1) indicates that plant fibres are similar in ash (silicates) and cellulose, higher in hemicellulose (pentosans) and lower in lignin content if compared to softwood fibres. From this general information one could suppose that non-wood fibres can be suitable or cheap pulping ${ }^{38}$ especially by mechanical based processes. 
Table 1. Chemical and elemental composition of bagasse, coconut banana and arrow root fibres.

\begin{tabular}{|c|c|c|c|c|c|c|c|c|c|c|}
\hline \multirow{2}{*}{$\begin{array}{l}\text { Nature of the } \\
\text { fibre }\end{array}$} & \multicolumn{6}{|c|}{$\begin{array}{c}\text { Chemical composition }(\%) \\
{[ \pm \text { Cumulative standard deviation }]}\end{array}$} & \multicolumn{4}{|c|}{ Elemental composition (\%) } \\
\hline & Moisture & Lignin & Cellulose & Hemicellulose & Extractives & $\mathbf{C}$ & $\mathbf{O}$ & $\mathbf{H}$ & $\mathbf{N}$ & Ash \\
\hline Coconut coir & $\begin{array}{c}13.68 \\
{[ \pm 0.05]}\end{array}$ & $\begin{array}{c}46.48 \\
{[ \pm 1.73]}\end{array}$ & $\begin{array}{c}21.46 \\
{[ \pm 1.44]}\end{array}$ & $\begin{array}{c}12.36 \\
{[ \pm 2.34]}\end{array}$ & $\begin{array}{c}8.77 \\
{[ \pm 0.39]}\end{array}$ & $\begin{array}{c}46.22 \\
{[ \pm 0.03]}\end{array}$ & $\begin{array}{c}40.47 \\
{[ \pm 0.03]}\end{array}$ & $\begin{array}{c}5.44 \\
{[ \pm 0.03]}\end{array}$ & $\begin{array}{c}0.36 \\
{[ \pm 0.002]}\end{array}$ & $\begin{array}{c}1.05 \\
{[ \pm 0.05]}\end{array}$ \\
\hline Coconut sheath & $\begin{array}{c}5.90 \\
{[ \pm 1.84]}\end{array}$ & $\begin{array}{c}29.7 \\
{[ \pm 4.36]}\end{array}$ & $\begin{array}{c}31.05 \\
{[ \pm 2.88]}\end{array}$ & $\begin{array}{c}19.22 \\
{[ \pm 3.46]}\end{array}$ & $\begin{array}{c}1.74 \\
{[ \pm 0.71]}\end{array}$ & $\begin{array}{l}42.23 \\
{[ \pm 0.21]}\end{array}$ & $\begin{array}{c}45.57 \\
{[ \pm 0.23]}\end{array}$ & $\begin{array}{c}5.69 \\
{[ \pm 0.03]}\end{array}$ & $\begin{array}{c}0.44 \\
{[ \pm 0.002]}\end{array}$ & $\begin{array}{c}8.39 \\
{[ \pm 0.03]}\end{array}$ \\
\hline Bagasse & $\begin{array}{c}5.64 \\
{[ \pm 1.60]}\end{array}$ & $\begin{array}{c}22.56 \\
{[ \pm 2.26]}\end{array}$ & $\begin{array}{c}39.45 \\
{[ \pm 2.41]}\end{array}$ & $\begin{array}{c}26.97 \\
{[ \pm 2.52]}\end{array}$ & $\begin{array}{c}4.33 \\
{[ \pm 0.74]}\end{array}$ & $\begin{array}{c}48.6^{*} \\
* *\end{array}$ & $\begin{array}{l}45.1^{*} \\
* *\end{array}$ & $\begin{array}{c}6.3^{*} \\
* *\end{array}$ & $\begin{array}{l}* * \\
* *\end{array}$ & $\begin{array}{l}3.5 * \\
* *\end{array}$ \\
\hline $\begin{array}{l}\text { Banana trunk } \\
\text { (Guad.) }\end{array}$ & $\begin{array}{c}9.74 \\
{[ \pm 1.42]}\end{array}$ & $\begin{array}{c}15.07 \\
{[ \pm 0.66]}\end{array}$ & $\begin{array}{c}31.48 \\
{[ \pm 3.61]}\end{array}$ & $\begin{array}{c}14.98 \\
{[ \pm 2.03]}\end{array}$ & $\begin{array}{c}4.46 \\
{[ \pm 0.11]}\end{array}$ & $\begin{array}{c}36.83 \\
{[ \pm 0.18]}\end{array}$ & $\begin{array}{c}43.62 \\
{[ \pm 0.22]}\end{array}$ & $\begin{array}{c}5.19 \\
{[ \pm 0.02]}\end{array}$ & $\begin{array}{c}0.93 \\
{[ \pm 0.005]}\end{array}$ & $\begin{array}{c}8.65 \\
{[ \pm 0.03]}\end{array}$ \\
\hline $\begin{array}{l}\text { Banana trunk } \\
\text { (Brazil) }\end{array}$ & $* *$ & 5 & $63-64$ & 19 & $* *$ & $* *$ & $* *$ & $* *$ & $* *$ & $* *$ \\
\hline Banana leaf & $\begin{array}{c}11.69 \\
{[ \pm 0.03]}\end{array}$ & $\begin{array}{c}24.84 \\
{[ \pm 1.32]}\end{array}$ & $\begin{array}{c}25.65 \\
{[ \pm 1.42]}\end{array}$ & $\begin{array}{c}17.04 \\
{[ \pm 1.11]}\end{array}$ & $\begin{array}{c}9.84 \\
{[ \pm 0.11]}\end{array}$ & $\begin{array}{c}44.01 \\
{[ \pm 0.22]}\end{array}$ & $\begin{array}{c}38.84 \\
{[ \pm 0.19]}\end{array}$ & $\begin{array}{c}6.10 \\
{[ \pm 0.03]}\end{array}$ & $\begin{array}{c}1.36 \\
{[ \pm 0.007]}\end{array}$ & $\begin{array}{c}7.02 \\
{[ \pm 0.03]}\end{array}$ \\
\hline Arrow Root D1 & 10.68 & 26.96 & 37.73 & 31.70 & 2.51 & $* *$ & $* *$ & $* *$ & $* *$ & $* *$ \\
\hline Arrow Root D2 & 11.36 & 22.50 & 39.99 & 31.19 & 3.77 & $* *$ & $* *$ & $* *$ & $* *$ & *** \\
\hline Sisal & $* *$ & $7.6-9.2$ & $43-56$ & $21-24$ & $* *$ & $* *$ & $* *$ & $* *$ & $* *$ & $* *$ \\
\hline Softwood & $* *$ & $26-34$ & $40-45$ & $7-14$ & $* *$ & $* *$ & $* *$ & $* *$ & $* *$ & $* *$ \\
\hline
\end{tabular}

$*$ Ouensanga $^{34}, * *$ not determined, the values are expressed in weight percent of the dry fibre, Guad.= Guadeloupe.

As reported by Marquez-Montesino et al. ${ }^{37}$ the variations of botanical composition are related to the physiologic age of the plant (age and localization in the plant) and to the species, agropedologic and climate conditions of the growing plant when comparing banana trunk from Brazil and Guadeloupe for example. Nevertheless, comparing to other vegetables studied, coco, bagasse and banana fibres ${ }^{3,36}$, arrow roots fibres are the richest in hemicellulose.

Elemental analysis was conducted on ashes at the Centre National de la Recherche Scientifique (CNRS) in Solaize, France, using a classical elemental analyzer. The contents of $\mathrm{C}, \mathrm{H}, \mathrm{O}$ and $\mathrm{N}$ vary with the location of the studied sample in the tree. When statistical analyses are performed, it is confirmed that banana and coconut raw fibres do not have similar elemental composition. For both species, the highest relative ratios by mass are obtained for carbon and oxygen, particularly for banana leaf and coconut coir in the case of carbon, banana stem and coconut sheath for oxygen. The upper part of the trees (leaves and fruits) contains more carbon while more oxygen is located in the lower part of the tree (trunk and leave sheaths). In fact, the contents of C, $\mathrm{H}$ and $\mathrm{O}$ elements vary with location in the tree, as shown by Marquez-Montesino et al. ${ }^{37}$ for eucalyptus.

\subsection{Morphology}

The microstructures of the fibres were characterized using scanning electron microscopy (SEM) after coating with gold or iridium.

The SEM images of the cross-section of the fibres after fracture are presented in Figure 1a-1e for coconut, bagasse and banana pyrolyzed fibres. The cross section (shapes, diameters) of the fibres are different from one botanical species to another.

The fibres agglomerate into bundles of unitary hollow fibres. These unitary fibres are generally designated as "wood cells" in vegetable physiology $y^{5,39}$. The hollow internal part of the cell is the lumen. In this paper, we will refer to the bundle as the "fibre", and the wood cell as the "cell".

The internal diameters and the wall thickness of the wood cells exhibited significant statistical variations. Table 2 includes estimates of wall thickness, fraction of material, density of cells and length of contact zone between cells per surface area. The fraction of material has been calculated using Equation 1:

fraction of material $=\frac{(\text { surface of fiber }- \text { surface of lumen })}{\text { surface of fiber }}$

All the material parameters that were used in the estimation of material fraction were obtained from the SEM observations, as a tridimensional expansion from the surface observation to volume. These calculations were made using the hypothesis of elliptical unitary fibres. They show that the fraction of material was between 0.5 and 0.7 . Also, the density of cells varies between 4534 and 14298 cells $/ \mathrm{mm}^{2}$ in the cross section of the fibre. Higher densities of cells were observed for coconut sheath and banana leaf fibres, while the lower values were obtained for bagasse fibres. In contrast, the interface between cells is greater in banana leaf fibres, and lower in the sugar cane bagasse fibres. These characteristics can be of interest 1) to estimate the treatment effect over the different fibres and 2) to understand the fibre modifications.

\section{Chemical and Thermal Treatment of the Fibres}

To improve the behaviour under aging of the vegetable fibres reinforced composites, there are two techniques: 1) modification of the matrix ${ }^{4,5}$, and 2) fibre treatment ${ }^{6,7}$. This second approach is presented in the paper; it can present the advantage of improving the fibre/ 
Coco coir fibre

Left x 250

Right x 1200

Zoom x 4000

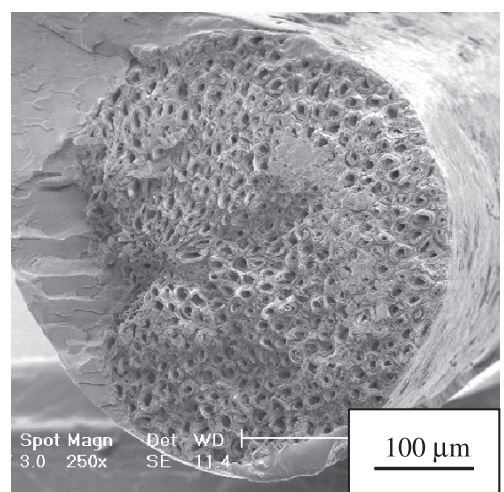

(a)

Coco sheath fibre

Left x 250

Right x 1200

Zoom x 4000

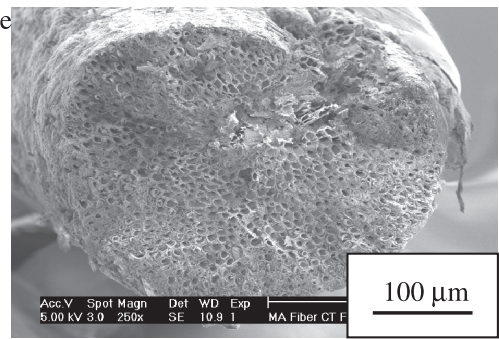

(b)

Sugar cane bagasse fibre

Left x 200

Right x 1200
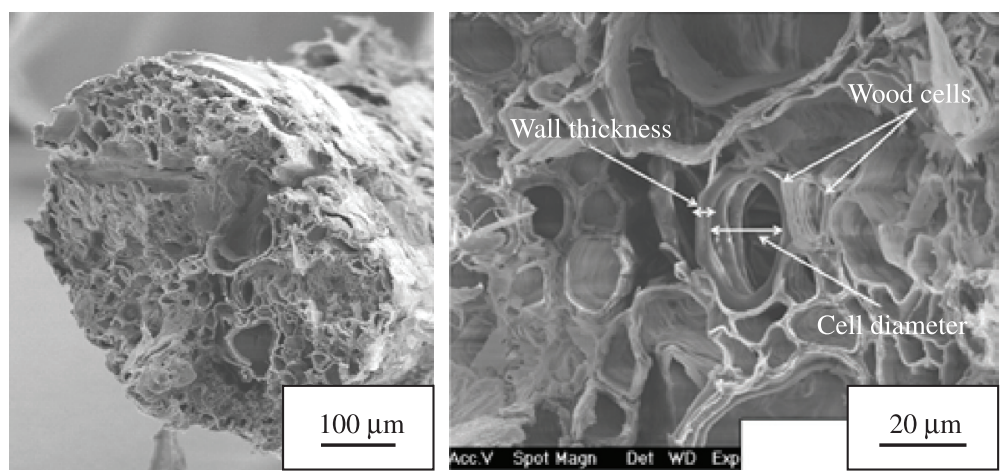

(c)

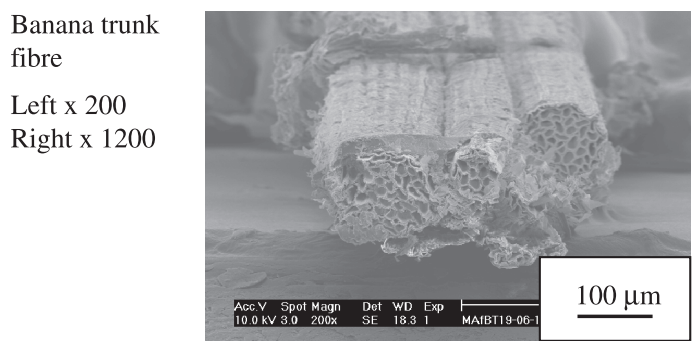

(d)
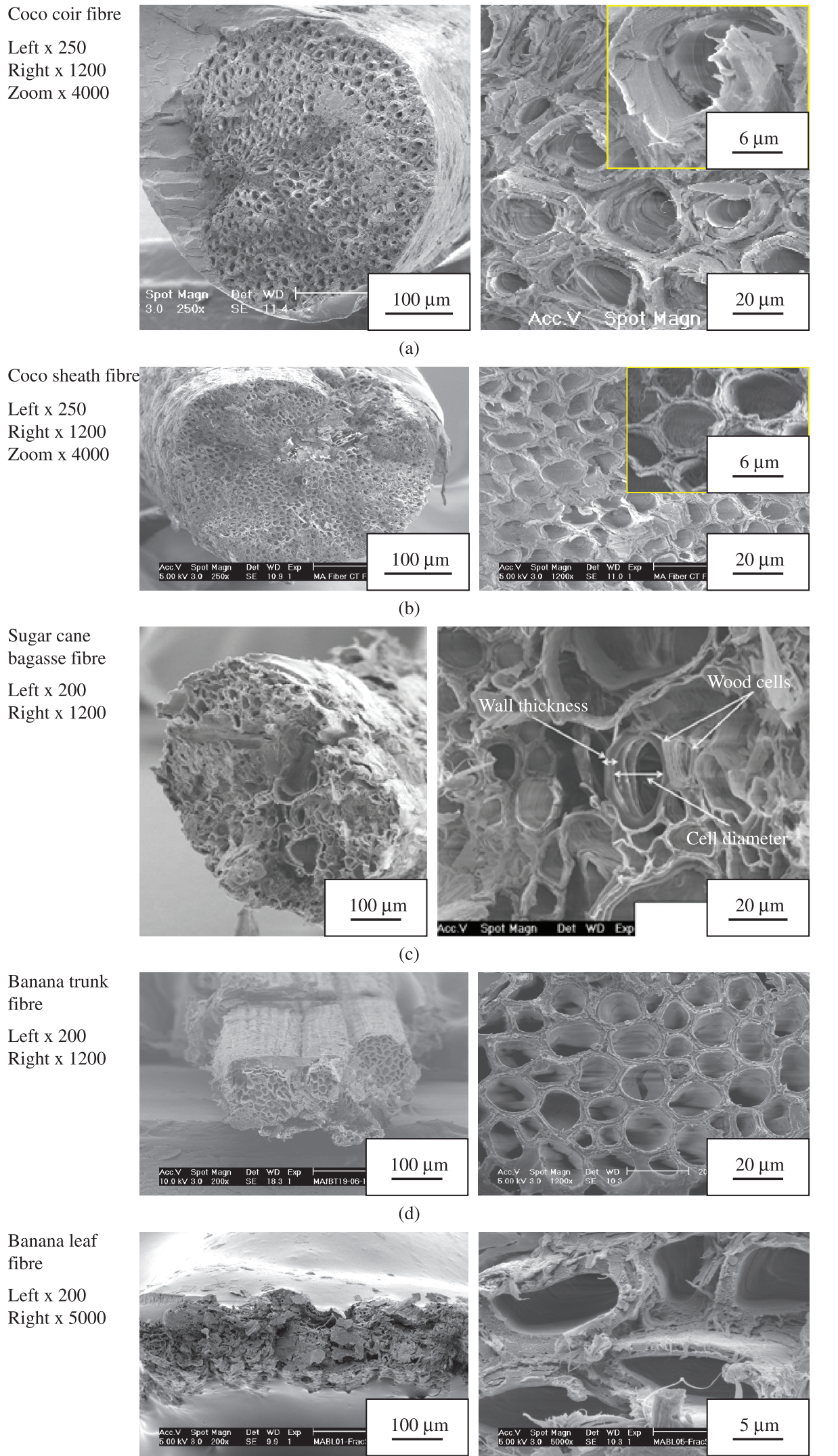
Table 2. Morphologic data of the cells/fibre characteristics.

\begin{tabular}{|c|c|c|c|c|}
\hline \multirow[t]{2}{*}{ Nature of the fibre } & \multicolumn{4}{|c|}{ Cells /Fibre characteristics } \\
\hline & D/d & Surface density of cells $\left(\mathrm{cell} / \mathrm{mm}^{2}\right)$ & Fraction of material & Interface* $^{*}(1 / \mu \mathrm{m})$ \\
\hline Sugar cane & 1.68 & 4534 & 0.596 & 0.230 \\
\hline bagasse & {$[ \pm 0.27]$} & {$[ \pm 1820]$} & {$[ \pm 0.113]$} & {$[ \pm 0.044]$} \\
\hline \multirow[t]{2}{*}{ Coconut coir } & 1.65 & 11989 & 0.671 & 0.381 \\
\hline & {$[ \pm 0.18]$} & {$[ \pm 2255]$} & {$[ \pm 0.122]$} & {$[ \pm 0.033]$} \\
\hline \multirow[t]{2}{*}{ Coconut sheath } & 2.21 & 14298 & 0.552 & 0.427 \\
\hline & {$[ \pm 0.81]$} & {$[ \pm 5866]$} & {$[ \pm 0.081]$} & {$[ \pm 0.100]$} \\
\hline \multirow[t]{2}{*}{ Banana trunk } & 2.64 & 6963 & 0.507 & 0.311 \\
\hline & {$[ \pm 1.17]$} & {$[ \pm 565]$} & {$[ \pm 0.107]$} & {$[ \pm 0.036]$} \\
\hline \multirow[t]{2}{*}{ Banana leaf } & 2.558 & 13054 & 0.689 & 0.734 \\
\hline & {$[ \pm 0.62]$} & {$[ \pm 729]$} & {$[ \pm 0.006]$} & {$[ \pm 0.200]$} \\
\hline
\end{tabular}

The standard variation of the data is reported between brackets. *The length of the interface between cells appearing at the surface of the fibre has been calculated as: Interface $(1 / \mu \mathrm{m})=$ density of cells* mean perimeter of cells $/ 2$.

matrix interface. Many treatments have been applied to vegetable fibres in the effort to prepare them for practical applications $\mathrm{s}^{8,9,40-60}$. The chemical treatments most widely used on vegetable fibres are acid hydrolysis and alkaline treatment ${ }^{40}$. These treatments include the well known delignification processes. Vegetable fibres have also been subjected to modifications that accelerate their degradation into monosaccharides ${ }^{48}$. Pulping of vegetable fibres is also used in the paper industry to eliminate or reduce the amounts of lignin and hemicellulose $\mathrm{e}^{40,42}$. Finally, pyrolysis has been extensively studied ${ }^{53-60}$.

\subsection{Alkali treatments}

All the ester-linked molecules of the hemicellulose and other cell-wall components can be cleaved by alkali. This tends to increase the hydrophilicity and hence the solubility of the material ${ }^{41}$.

Alkali treatment of lignocellulosic substances disrupts the cell wall, dissolves hemicellulose and lignin by hydrolyzing acetic acid esters and by swelling cellulose, and decreases the crystallinity of cellulose $e^{40}$. The biodegradability of the cell wall increases, due to the cleavage of the bonds between lignin and hemicellulose or between lignin and cellulose $\mathrm{e}^{40}$.

\subsection{Acid treatments}

The effects of acid treatments on vegetable fibres ${ }^{47}$ vary with the nature and concentration of the acid, and with the temperature of the experiment. The hemicelluloses are very sensitive to acid hydrolysis, and are easily hydrolyzed by acids ${ }^{40,48}$. By hydrolysis they form their correspondent monomer elements.

The actuation of the acid on the cellulose chain can entail the attack of glucosidic bonds by hydronium ions. It also induces the failure of the microfibrils and the separation of the constituents of the fibre.

The lignin in hardwood species is partly dissolved by sulfuric acid during the acid hydrolysis ${ }^{40}$. The acid treatment decreases the aliphatic hydroxyl content and consequently decreases the polarity of the lignin molecules without derivatization, but enhances the antioxidant properties ${ }^{52}$.

\subsection{Pyrolysis treatments}

The first process in the thermal decomposition of the vegetable materials corresponds to the hemicellulose decomposition ${ }^{53,54}$.

Shafizadeh ${ }^{53}$ has studied the thermal decomposition of cellulose. He found that, below $300^{\circ} \mathrm{C}$, this reaction results in the formation of char, water, carbon monoxide and carbon dioxide. However, between 300 and $500{ }^{\circ} \mathrm{C}$, pyrolysis results in the formation of tars that consist largely of anhydrous sugars, oligosaccharides, and dehydration of pyrans and furans. Above $500{ }^{\circ} \mathrm{C}$, flash pyrolysis produces volatiles or gaseous molecules of low molecular weight from secondary reactions of tars and the interaction between char, water and $\mathrm{CO}_{2}$ at high temperature. Cellulose degradation is the second process in the decomposition of the lignocellulosic material, as observed in almond chars by Marcilla et al. ${ }^{54}$.

The pyrolysis of lignin occurs in inert atmospheres at high temperatures over a wide temperature domain ${ }^{55,57}$. The thermal decomposition of the lignin is also affected by the acid pretreatment used for cellulose extraction ${ }^{47}$. This is responsible for the breakdown of the three-dimensional structure of lignin.

A combination of chemical or thermal treatment can also be carried out ${ }^{47,59,60}$. Both acid and alkaline treatments are proposed by Abou-Yousef et al. ${ }^{59}$ for sugar cane delignification, hydrothermal and alkali pulp treatment ${ }^{60}$, acid and thermal treatment ${ }^{47}$.

\subsection{Coating with silanes}

Alkyltrialkoxysilanes R'Si(OR) ${ }_{3}$ are used in many industrial application as coupling agents to improve the adhesion between polymeric matrices and inorganic materials. They have also been used in vegetable fibrepolymer composites ${ }^{5,61}$ to modify fibre surface. The mechanism of these coupling reactions is related to the effect of two reactive surface groups and these reactions are different according to the substrate in contact. Alkoxy groups (OR) allow the silane to bind to surface $\mathrm{OH}$ groups after hydrolysis. Additionally, the alkyl groups R' increase the compatibility with the organic compounds 
and the hydrophobic character of the surface, leading to an enhancement in the strength of the interface in the polymer matrix. Usually, silane treatment is carried out with a diluted silane solution at $0.2 \%$ to $20 \%$ by weight ${ }^{10,62}$. These conditions have the following advantages:

- Increase in the silane solubility;

- Improvement in the thickness of the surface film;

- Development of a uniform cover on the surface.

Water produces moderate hydrolysis of the silane and leads to silanol. This behavior allows the adhesion of silanes onto the $\mathrm{OH}$ groups of the fibre substrate.

After solvent evaporation, the residual silanol groups can condense with the hydroxyl groups of the substrate, or can lead, by «self-condensation» reactions, to a polysiloxane network on the surface. In aqueous media, partially or totally hydrolyzed silanes are reactive molecules that change with time by self-condensation of silanol groups or condensation of silanol with alkoxy groups to form dimers or oligomers. They are commonly used as commercial water repellents. In the case of VFRC with softwood or hardwood pulps, silane treatment has been found to increase moisture-cycling resistance ${ }^{11}$.

\section{Pulping}

Cellulose fibre-cement sheets prepared by Hatschek method to be applied to low cost construction is still in need of some studies related to processes and raw material conformation. Softwood kraft pulp is approximately priced US $\$ 800 / t^{63}$ and represents $\sim 10 \%$ by mass of cement matrix as practiced in commercial autoclaved products. Since the mentioned fibres are to be refined before their use as cement reinforcement even higher costs are to be expected, grading the fibres as an expensive raw material in the composite preparation.

As a contribution for viable fibre-cement materials in developing tropical countries this work proposes the use of alternative waste fibres of sisal and banana for thermomechanical based pulping procedures in comparison with the chemical Kraft process applied to the same non wood fibres.

The use of fibres from natural plants can help to save wood plantations for applications in which no immediate substitute is available. Bhargava et al. ${ }^{64}$ and Murthy et al. ${ }^{65}$ presented promising results from sisal pulped by chemical methods although effluents disposal and also availability of strand fibres are usual concerns.

Regardless of high-energy consumption, mechanical pulping presents a range of advantages over chemical pulps. As appointed by Coutts and Ridikas ${ }^{66}$, effluent treatment and disposal are less troublesome, chemical requirements are lower, pulp price is cheaper (around half the price of kraft pulp) and mills find economical viability at small scale.

\subsection{Mechanical pulping}

As exposed by Higgins ${ }^{67}$ for softwood pulping, low temperature thermo-mechanical processes with defibration temperatures in vicinity of $130{ }^{\circ} \mathrm{C}$ are expected to provide well-fibrillated fibres, although with some fibre damage incidence. Higher temperatures $\left(135-170{ }^{\circ} \mathrm{C}\right)$ are supposed to provide no fibrillation and also smooth lignin-encased fibres, with poor bonding and beating properties and also with low conformability of the fibres.

\subsection{Kraft pulping}

Kraft or sulphate process is considered the predominant procedure for pulping all over the world. In the Kraft process that is used in the papermaking industry ${ }^{42}$, the alkaline reactant is a mixture of sodium hydroxide, sodium sulphite and sodium carbonate ${ }^{42-45}$. Other alkaline solutions include sodium hydroxide ${ }^{43-46}$, soda-anthraquinone ${ }^{43,44}$, sulfiteanthraquinone ${ }^{44}$, alkaline sulphite anthraquinone ${ }^{44}$, calcium hydroxide ${ }^{46}$, potassium hydroxide ${ }^{46}$, lithium hydroxide ${ }^{465}$, ammonia $^{46}$ and hydrogen peroxides ${ }^{46}$.

\section{Experimental}

\subsection{Chemical and thermal treatment of the fibres}

\subsubsection{Fibre processing}

Vegetable fibres of the island of Guadeloupe (French West Indies) obtained from agricultural harvests of sugar cane, banana, coconut trees, and arrow root were used in this study. The fibres were obtained from sugar cane residue while fibre strands were extracted from the leaves and trunks of banana which correspond to the two dominant agricultural products of the region. Fibres were also extracted from coconut fruit and extracted from sheaths of young leaves. Although in other tropical countries, the coconut fibres are often used in part for the production of carpets, brush, broom, there are no current industrial or agro-industrial applications of such fibres in Guadeloupe.

Sugar cane bagasse (Saccharum officinarum) - The sugar cane bagasse, denoted as "B"-, is supplied by the Montebello distillery (Petit-Bourg, Guadeloupe) It is used mainly as fuel in the same factory. However, there is still an excess of $~ 30 \%$ of the total yield. It is milled using a laboratory blender and sieved to obtain fibre with controlled diameter, as received sugar cane bagasse, obtained from the factory had variable sizes. The pieces of bagasse were $\sim 5 \mathrm{~cm} \times 2 \mathrm{~cm}$.

Banana tree (Musa acuminata) was obtained from a plantation. Banana fibres from the trunk are denoted "BT", while those from the leaves as "BL". After harvesting the fruits, the segment of the plant above the bottom will die. However, a new plant is formed at the bottom. The dead segment is cut and partly used as fertilizer in the fields. The stem is cut and rinsed in tap water. It is then air dried for at least one week before drying it in an oven for 2 hours. The banana trunk pieces ( size $\sim 3 \mathrm{~cm} \times 3 \mathrm{~cm}$ ) were prepared in the laboratory at Guadeloupe. They were soaked in deionized water at the temperature of $24^{\circ} \mathrm{C}$ for around 16 hours before being air-dried.

Coconut fibres (Cocos nucifera L.) were extracted from the fruit or from the sheath of coconut leaves. The coconut fibres were obtained from the fruit husk that is also called the coir. These are denoted as "CC", while those from the sheath of young coconut leaves are described as "CT". The sheath of young coconut leaves is found between the trunk and the leaves remaining around the trunk. 
The untreated banana and coconut fibres were obtained after milling using a laboratory blender. To improve the physical properties of the fibres under study, three different treatments - pyrolisis, alkaline and acid - were applied.

Arrow root (Maranta Arundinacea) fibres are waste of flour extraction from the rhizome. They were air dried, crushed and sieved. Fibres from two harvests within 6 months interval noted as D1 and D2 were studied.

The alkaline treatment procedure consisted of boiling the fibre for 1 hour in a solution of $5 \%$ by mass of $\mathrm{Ca}(\mathrm{OH})_{2}$, while the acid treatment was carried out in a solution of $5 \%$ by mass of $\mathrm{H}_{2} \mathrm{SO}_{4}$. The fibres were then rinsed and kept for 2 hours in deionized water to make sure that all the water-soluble chemicals and by-products were removed. After drying, the fibres were separated by milling. The alkali-treated fibres "BB" and "BTB" on one hand and the acid-treated fibres "BA" and "BTA" were obtained from, respectively, sugar cane bagasse and banana trunk fibres.

The thermal, pyrolysis, treatment was conducted in an inert atmosphere (without oxygen) to prevent combustion, i. e. the total transformation of organic matter into $\mathrm{CO}_{2}$ and $\mathrm{H}_{2} \mathrm{O}$. Further explanation regarding the details of the pyrolysis treatment is available elsewhere ${ }^{5,20,36}$.

The pyrolysis of bagasse (at temperatures up to $200^{\circ} \mathrm{C}$ ) results in the dehydration and rearrangement of carbohydrates (cellulose and hemicellulose). It also causes a partial dehydration of lignin in the fibres ${ }^{36}$. At $200{ }^{\circ} \mathrm{C}$, the loss of material due to pyrolysis is still low, and only the extractives and hydrogen bonds are destroyed ${ }^{35,36}$. The extractives are also more sensitive to water solubility. Therefore, in this study, the screened fibres were heat treated at $200{ }^{\circ} \mathrm{C}$ for 2 hours. To make sure that the oven environment is totally oxygen free, the nitrogen flow in the oven was adjusted to our experimental pyrolysis setup ( $\sim 2 \mathrm{~L} / \mathrm{h}$ at atmospheric pressure). The pyrolyzed bagasse and banana trunk fibres are designated respectively "BP" and "BTP".

Fibres with lengths of approximately $10 \mathrm{~mm}$ were sieved through $0.4 \mathrm{~mm}$ and $1 \mathrm{~mm}$ mesh screen to select fibres with diameters between $0.4 \mathrm{~mm}$ and $1 \mathrm{~mm}$. This was done for the pyrolyzed, alkaline and acid treated fibres.

Two commercial alkylalkoxysilanes provided by SigmaAldrich company, commonly termed silanes $S_{1}$ and $S_{2}$ in the text, were used. $S_{1}$ is in fact an alkyltrialkoxysilane $\left(\mathrm{RSi}(\mathrm{OR})_{3}\right)$ while $\mathrm{S}_{2}$ is a dialkyldialkoxysilane $\left(\mathrm{R}_{2} \mathrm{Si}(\mathrm{OR} \text { "' })_{2}\right)$. Silane coating was performed by stirring an immersion of $5 \mathrm{~g}$ of fibre in an emulsion of silane for 2 hours. These treatments were performed on unpyrolyzed and pyrolyzed fibres, for both alkylalkoxysilanes $S_{1}$ and $S_{2}$ and with various volume fractions " $\mathrm{X}$ " of silane. Fibre treated in a solution with $\mathrm{X} \%$ of silane $S_{i}$ is designed "PBXS," for pyrolyzed fibres and "BXS." for unpyrolyzed fibres.

\subsubsection{Techniques of analysis}

The length, width and thickness of untreated and treated fibres (unpyrolyzed and pyrolyzed, chemically treated, silane coated) were measured using an optical microscope NIKON SMZ1000 (Japan). 90 to 200 samples were studied in order to perform a statistical analysis of the results.
After coating with gold, the cross-section and the surface of the fibres were examined using Scanning Electron Microscopy (SEM) in secondary electron mode (SE).

Chemical analyses of the fibres were carried out using classical methods described in section 2.2. X-Ray Photoelectron Spectroscopy (XPS) Analysis. In order to control the adhesion of silanes on bagasse fibre surface, a structural analysis of the chemical bond present on the fibre surface and $1 \mathrm{~nm}$ under the surface was performed on bagasse fibre, by XPS. The surface area analysed was $150 \mu \mathrm{m}$ in diameter and the thickness was 1-2 $\mathrm{nm}$.

Porosity of the fibres was studied by mercury intrusion porosimetry from 0.1 to $200 \mathrm{MPa}$ with THERMOFINNIGAN Pascal 140 and Pascal 240 mercury porosimeters. This range of pressure corresponds to pore radius from 3.7 to $58000 \mathrm{~nm}$.

The hygroscopic character of the fibres was estimated by introducing 100-180 mg of fibres into a closed container under controlled static pressure of water. Partial pressure of water was regulated at $0.83 \mathrm{P}_{0}\left(\mathrm{P}_{0}\right.$ : saturation vapor pressure of pure water) using a saturated solution of potassium chloride $\mathrm{KCl}$, at the temperature of $35^{\circ} \mathrm{C}^{68}$. Water uptake was measured at 24 hours intervals until weight stabilization was obtained.

The fibre strength tests were performed in air at room temperature $\left(25^{\circ} \mathrm{C}\right)$ and relative humidity of $40-45 \%$. The tests were conducted on treated and untreated fibres. At least 20 samples were tested to obtain representative fibre tensile strengths in each condition. The tests were carried out on $1 \mathrm{~cm}$ long fibres in a Chatillon mini-testing device (Chatillon Itin Scale, Brooklin, NY). The fibres were loaded continuously to failure at a cross-head displacement rate of $0.2 \mathrm{~mm} / \mathrm{s}$. The fibres tensile strengths were thus determined from the ratios of the fracture loads and the initial cross section of the fibre prior to testing. The variability in the fibre strengths was characterized using different probability density functions. This was done using the Minitab commercial software package (Minitab Inc., State College, PA, USA).

\subsection{Pulping}

Sisal (Agave sisalana) field by-product was provided by Associação de Pequenos Produtores do Município de Valente (Apaeb), state of Bahia, Brazil. The sisal wastes are predominantly generated during the decorticating processes and demand just a simple cleaning from mucilage residues by manual cylindrical rotary sieve.

High standard quality mechanically combed Tanzanian sisal fibers provided by Geo. Kinnear \& Sons P/L, Melbourne, Australia were used for comparison with the waste fibres presented above and preliminary adjustment of mechanical pulping procedures applied to non-wood materials.

Banana (Musa cavendishii) pseudo-stem, grown by Magário Plantations, Registro, state of São Paulo, Brazil has been used for pulp preparation. The banana strands were obtained using a manual cane crasher adapted with the main purpose of moisture extraction.

All the strand fibres were cut to approximately $30 \mathrm{~mm}$ length and submitted to low temperature thermo-mechanical pulp (TMP) or chemi-thermo-mechanical pulp (CTMP) as reported in Tables 3 and 4 respectively in keeping with 
Table 3. TMP process for commercial sisal strands.

\begin{tabular}{cc}
\hline Initial preparation & Soaking in hot water for at least $16 \mathrm{~h}^{(1)}$ \\
Thermo-mechanical defibration $^{(2)}$ & $172 \mathrm{kPa}$ steam gauge pressure $\left(130{ }^{\circ} \mathrm{C}\right), 120 \mathrm{~s}$ pre-steaming, $90 \mathrm{~s}$ defibration \\
Straight closed periphery plates refinement ${ }^{(3,4)}$ & $1270 \mu \mathrm{m}$ clearance -1 pass \\
& $635 \mu \mathrm{m}$ clearance -1 pass \\
& $254 \mu \mathrm{m}$ clearance -1 pass \\
Straight open periphery plates refinement ${ }^{(3,5)}$ & $127 \mu \mathrm{m}$ clearance -1 pass \\
& $508 \mu \mathrm{m}$ clearance -1 pass \\
$254 \mu \mathrm{m}$ clearance -2 passes \\
$127 \mu \mathrm{m}$ clearance -1 pass
\end{tabular}

(1) The initial temperature was aprox. $60{ }^{\circ} \mathrm{C}$ and then it dropped down until equilibrium with ambient. (2) Asplund laboratory defibrator. (3) Bauer 20-cm laboratory disc refiner. (4) Pulp partially de-watered prior to $127 \mu \mathrm{m}$ clearance pass. (5) Pulp partially de-watered prior to $254 \mu \mathrm{m}$ clearance $2^{\text {nd }}$ pass and $127 \mu \mathrm{m}$ clearance pass.

Table 4. CTMP process for sisal and banana strands.

\begin{tabular}{|c|c|c|c|}
\hline \multicolumn{2}{|l|}{ Fibre } & Commercial sisal & By-product sisal and banana \\
\hline \multicolumn{2}{|l|}{ Initial preparation } & \multicolumn{2}{|l|}{ Soaking in cold water for at least $16 \mathrm{~h}$} \\
\hline \multicolumn{2}{|l|}{ Chemical pretreatment } & \multicolumn{2}{|c|}{$\begin{array}{l}1 \mathrm{~h} \text { cooking in boiling lime liquor }(10 \% \quad 1 \mathrm{~h} \text { cooking in boiling lime liquor (10\% of } \\
\text { of lime based in strands mass; } 23.3: 1 \text { lime based in strands mass; } 33.3: 1 \text { liquor:fibre } \\
\text { liquor:fibre ratio by mass) }\end{array}$} \\
\hline \multicolumn{2}{|l|}{ Thermo-mechanical defibration $^{(1)}$} & \multicolumn{2}{|c|}{$\begin{array}{l}103 \mathrm{kPa} \text { steam gauge pressure }\left(121^{\circ} \mathrm{C}\right), 120 \mathrm{~s} \text { pre-steaming, } 90 \mathrm{~s} \text { defibration in presence } \\
\text { of } 400 \mathrm{~mL} \text { of the pretreatment solution }\end{array}$} \\
\hline \multirow{4}{*}{$\begin{array}{l}\text { Straight open periphery plates } \\
\text { refinement }{ }^{(2)} \text { with clearances } \\
(\mu \mathrm{m}) \text { : }\end{array}$} & 1270 & 1 pass & - \\
\hline & 508 & 1 pass & - \\
\hline & 254 & 1 pass & 1 pass \\
\hline & 127 & 1 pass & - \\
\hline \multirow{2}{*}{$\begin{array}{l}\text { Straight closed periphery plates } \\
\text { refinement }{ }^{(2)} \text { with clearances } \\
(\mu \mathrm{m}) \text { : }\end{array}$} & 127 & 2 passes & 1 pass \\
\hline & 76 & - & 1 pass \\
\hline
\end{tabular}

(1) Asplund laboratory defibrator. (2) Bauer 20-cm laboratory disc refiner; pulp partially de-watered before each refinement pass.

Table 5. Sisal and banana Kraft pulping conditions.

\begin{tabular}{lccc}
\hline \multicolumn{1}{c}{ Parameter } & & Fibre \\
\cline { 3 - 4 } & & Sisal & Banana \\
\hline Active alkali $\left(\right.$ as Na $\left._{2} \mathrm{O}\right)(\%)$ & & 9 & 10 \\
Sulfidity $\left(\right.$ as $\left.\mathrm{Na}_{2} \mathrm{O}\right)(\%)$ & & 25 & 25 \\
Liquor/fibre ratio & & $5: 1$ & $7: 1$ \\
Temperature $\left({ }^{\circ} \mathrm{C}\right)$ & Pre-heating & 170 & 170 \\
Digestion time (min) & Cooking & $\sim 75$ & $\sim 85$ \\
& & 120 & 120 \\
\hline
\end{tabular}

Ramos et al. ${ }^{69}$ and Higgins et al. ${ }^{70}$. Kraft pulping was also adopted in an attempt to serve as a reference pulping process (Table 5).

\subsubsection{Mechanical pulping}

The commercial strand fibres required high energy application during Bauer refiner steps (8 passes for TMP and 6 passes for CTMP, as shown in Tables 3 and 4) denoting some deficiency in the Asplund thermomechanical defibration. Also the screened yields of these pulps (Table 6) were higher than those of waste based pulps.

At the present CTMP study, chemical pre-treatment based on saturated solution of calcium hydroxide provided adequate attack on the strands. The interest in using lime (instead of caustic soda, for example) relied on cost reduction and environmental safety.

Only three passes through the Bauer refiner were enough to achieve considerable reduction after Asplund defibration over sisal and banana residual raw materials (Table 4). The reduction on energy consumption performed the most attractive aspect for the low-cost pulp production, since the price of strand wastes was found negligible.

\subsubsection{Kraft pulping}

The production of sisal and banana kraft pulp in the lab was composed by the cooking of the raw material under controlled conditions. A mixture of sodium hydroxide and sodium sulfide in water solution followed the procedures adopted in prior studies ${ }^{13,71-73}$ that are detailed in Table 5. 
Table 6. Pulp and fibre properties.

\begin{tabular}{|c|c|c|c|c|c|c|}
\hline Fibre & $\begin{array}{c}\text { Commercial } \\
\text { sisal TMP }\end{array}$ & $\begin{array}{l}\text { Commercial } \\
\text { sisal CTMP }\end{array}$ & $\begin{array}{l}\text { By-product } \\
\text { sisal CTMP }\end{array}$ & $\begin{array}{c}\text { Banana } \\
\text { CTMP }\end{array}$ & $\begin{array}{l}\text { By-product } \\
\text { sisal Kraft }\end{array}$ & $\begin{array}{c}\text { Banana } \\
\text { Kraft }\end{array}$ \\
\hline Screened yield (\%) & 58.5 & 73.2 & 43.4 & 35.6 & 45.5 & 45.3 \\
\hline Kappa number ${ }^{(1)}$ & 55.2 & 80.4 & 50.5 & 86.5 & 31.7 & 44.5 \\
\hline Freeness $(\mathrm{mL})^{(2)}$ & 5 & 224 & 500 & 465 & 650 & 222 \\
\hline Length-weighted average length (mm) & $2.46^{(3)}$ & $2.25^{(3)}$ & $1.53^{(4)}$ & $2.09^{(4)}$ & $1.66^{(4)}$ & $1.95^{(4)}$ \\
\hline Fines $(\%)^{(5)}$ & 3.88 & 2.34 & 2.14 & 1.55 & 3.31 & 6.86 \\
\hline Coarseness (mg/m) & N/A & N/A & 0.138 & 0.147 & 0.163 & 0.154 \\
\hline Fibre width $(\mu \mathrm{m})^{(6)}$ & 12.7 & 10.2 & 9.4 & 11.8 & 13.5 & 15.3 \\
\hline Aspect ratio & 194 & 221 & 163 & 177 & 123 & 127 \\
\hline
\end{tabular}

(1) Appita P201 m-86. (2) AS 1301.206s-88. (3) Galai WCIS-100 (2nd moment of inertia >1). (4) Kajaani FS-200. (5) Arithmetic basis. (6) Average of 20 determinations by SEM. N/A - not available data.

\subsubsection{Additional cleaning procedures}

Each pulp produced was passed through a $0.229 \mathrm{~mm}$ slotted Packer screen, vacuum de-watered, pressed, crumbed and stored in a sealed plastic bag under refrigeration. For CTMP from waste fibres a supplementary Somerville $0.180 \mathrm{~mm}$ mesh screening and washing was provided for separation of fines.

On the other hand, the screened yields of mechanical pulps from by-product sisal and banana (respectively $43 \%$ and $36 \%$ ) were much lower than could be expected ${ }^{14}$ especially if considered the low lignin content of those nonwood fibres (Table 1). However one should be aware that the reported yields are connected to the following peculiarities:

- Because of the high moisture content initially present in the raw material, the fibrous waste tends to decompose very fast, originating weak fibres significantly more sensible to pulping procedures, as appointed by Fernandes et al. ${ }^{74}$ and Misra ${ }^{75}$;

- As the residual strand fibres were initially cleaned by rude processes they appeared rich in pithy material and parenchyma cells which were mostly removed during pulping stages; and

- The Somerville mesh screening was effective in the reduction of fine amounts since the mechanical refinement caused intense damage on the fibres ${ }^{76}$.

\subsubsection{Test methods}

The pulping screened yield was defined as the ratio between the final net mass of the produced pulp divided by the initial mass of the fibrous residues used in the beginning of the pulping process. That was determined under dry basis of the materials mass obtained after at least 24 hours of permanency in the oven at $(105 \pm 5)^{\circ} \mathrm{C}$.

The Kappa number is an indirect laboratory measurement for the content of residual lignin present in the pulp commonly used in the paper industry in conjunction with bleaching related processes applied to pulps with yields lower than $70 \%$. The method relies on the permanganate consume that in acid solutions react fast with the lignin but slowly with cellulose. The procedures involved in this method are detailed in the AS 1301 (Appita P201 m-86) Standards. The interest in the determination of the Kappa number is linked with the degradation of vegetable fibres in alkaline environments (OPC, e.g.) and its relation with the lignin content of the fibre ${ }^{15}$.

The Canadian Standard Freeness (CSF) of each pulp was determined in accordance with AS-1301.206s-88. CSF is an arbitrary measure of the drainage properties of pulp suspensions and is associated with the initial drain rate of the wet pulp pad during the de-watering process ${ }^{66}$.

The length and coarseness of the fibres were determined using the optical analyzer Kajaani, FS-200 model ${ }^{77}$. The percent distribution of the filaments population and the average length were determined based in the concept of weighted mean that is less sensible to the proportion of existing fines ${ }^{78}$. For those coarse pulps the Kajaani equipment could not be applied due to the risk of capillary blockage, being substituted by the Galai stream-scanning particle size analyser ${ }^{77}$ using laser-based measurements to determine particle size and image analysis to determine particle shape.

Fines were defined as the particles with length less than $0.2 \mathrm{~mm}$ regardless of their nature or shape. The coarseness of the fibre is related to the cross section area of the cellular wall. This physical characteristic influences the total number of filaments present in the unitary mass of the sample, as well as the spatial configuration of the fibres net and also the individual strength of each filament ${ }^{76}$.

Fibres were vacuum gold coated and analysed in a Philips XL30 field emission gum (FEM) scanning electron microscope (SEM) using secondary electron (SE) detector, at accelerated voltages varying from 2.0 to $5.0 \mathrm{kV}$.

\section{Results and Discussion}

\subsection{Chemically and thermally treated fibres}

\subsubsection{Dimensional analysis}

Fibre dimensions and their standard deviations (length, width, thickness and aspect ratio) are summarized in Table 7. Distribution of length, wide, external surface of the fibres follow log-normal laws. Distribution of thickness measurements follows normal law distribution. There is a variability of dimensions according to standard deviation and botanical specie. 
Table 7. Effect of fibre treatment on aspect ratio.

\begin{tabular}{|c|c|c|c|c|c|c|c|c|}
\hline \multirow[t]{2}{*}{ Fibre } & \multicolumn{3}{|c|}{ Untreated fibre dimensions [st. dev.] } & \multicolumn{5}{|c|}{ Aspect ratio L/w } \\
\hline & $\begin{array}{c}\text { Length } \\
(\mathrm{mm})\end{array}$ & $\begin{array}{l}\text { Width } \\
(\mu m)\end{array}$ & $\begin{array}{l}\text { Thickness } \\
\quad(\mu \mathrm{m})\end{array}$ & Untreated & Pyrolysis & Acid & Alkaline & Silane \\
\hline Arrow Root (D1) & $\begin{array}{c}5.77 \\
{[ \pm 3.35]}\end{array}$ & $\begin{array}{c}140.48 \\
{[ \pm 86.14]}\end{array}$ & $\begin{array}{c}83.03 \\
{[ \pm 38.6]}\end{array}$ & $41-70$ & $41-82$ & nd & nd & nd \\
\hline Arrow Root (D2) & $\begin{array}{c}5.45 \\
{[ \pm 2.01]}\end{array}$ & $\begin{array}{c}104.17 \\
{[ \pm 46.98]}\end{array}$ & $\begin{array}{c}64.58 \\
{[ \pm 29.61]}\end{array}$ & $52-85$ & $43-59$ & nd & nd & nd \\
\hline Bagasse (B) & $\begin{array}{c}3.69 \\
\pm 2.15]\end{array}$ & $\begin{array}{c}567.5 \\
{[ \pm 329.4]}\end{array}$ & $\begin{array}{c}161.25 \\
{[ \pm 90.75]}\end{array}$ & $6.5-23$ & $6-23$ & $6-13$ & $4-15$ & $7-12$ \\
\hline Banana Trunk (BT) & $\begin{array}{c}1.9 \\
{[ \pm 0.64]}\end{array}$ & $\begin{array}{c}820.24 \\
{[ \pm 264.49]}\end{array}$ & $\begin{array}{c}150.29 \\
{[ \pm 86.94]}\end{array}$ & $2.3-12,6$ & $6-23$ & $8-19$ & $10-27$ & nd \\
\hline Banana Leaf (BL) & $\begin{array}{c}1.70 \\
{[ \pm 0.91]}\end{array}$ & $\begin{array}{c}834.52 \\
{[ \pm 245.94]}\end{array}$ & $\begin{array}{c}160.42 \\
{[ \pm 55.26]}\end{array}$ & $2-11$ & $2-16$ & nd & nd & nd \\
\hline Coconut Coir (CC1) & $\begin{array}{c}29.35 \\
{[ \pm 8.17]}\end{array}$ & $\begin{array}{c}331.78 \\
{[ \pm 198.72]}\end{array}$ & $\begin{array}{c}273.57 \\
{[ \pm 150.94]}\end{array}$ & $88-107$ & $84-103$ & nd & nd & nd \\
\hline Coconut Coir (CC2) & $\begin{array}{c}2.7 \\
{[ \pm 2.46]}\end{array}$ & $\begin{array}{c}683.21 \\
{[ \pm 279.42]}\end{array}$ & $\begin{array}{c}215 \\
{[ \pm 98.67]}\end{array}$ & $4-13$ & $3-10$ & nd & nd & nd \\
\hline Coconut Sheath $(\mathrm{CT})$ & $\begin{array}{c}5.47 \\
{[ \pm 3.08]}\end{array}$ & $\begin{array}{c}338.09 \\
\pm 258.23]\end{array}$ & $\begin{array}{c}177.68 \\
{[ \pm 134.76]}\end{array}$ & $16-31$ & $20-35$ & nd & nd & nd \\
\hline
\end{tabular}

nd : data non determined.

Maximum and minimum values of aspect ratio, L/w, are presented in the table. Aspect ratio is a determinant factor to evaluate efficiency of the fibre as reinforcement in composite materials. Most fibre present an aspect ratio higher than 10, except banana leaf fibres. Two types of coconut coir fibres are identified, long and fibrous (CC1) and spongy (CC2). The highest aspect ratio (>88) is observed for CC1, just before arrow-root fibres (D1 and D2) which aspect ratio varies from 40 to 80 . These values are strongly related to the milling process applied for fibre preparation. Untreated and pyrolyzed arrow root fibres with an aspect ratio $>80$ satisfy dimensional requirements for synthetic reinforcement fibres ${ }^{79,80}$.

Fibres with highest aspect ratio before pyrolysis (D or CC1) still present the highest values after pyrolysis.

After chemical treatment, a decrease of aspect ratio takes place in the case of bagasse fibre (B) and an increase in case of banana trunk fibre (BT). After coating the aspect ratio of bagasse fibre also decreases. A direct consequence of the increase in the external surface area observed after silane treatment that could be valuable, if the strength of the interface is preserved, is the improvement in composite properties due to a better contact between matrix and fibre.

\subsubsection{Texture}

SEM images indicate that pyrolysis treatments (Figures $2 \mathrm{~b}$ and $2 \mathrm{f}$ ) increase the surface roughness from the raw fibre state (Figures $2 \mathrm{a}$ and $2 \mathrm{e}$ ). Such roughing is thought to enhance the adhesion between the matrix and the fibre.

The SEM image (Figure 2d) reveals that the fibre skeleton is strongly damaged after alkali treatment. Furthermore, alkali treatment disrupts the cell wall and dissolves the matrices of wood materials that consist of hemicellulose and lignin. For banana trunk fibre (Figure 2h), it is not the same behavior, the amount of hemicellulose is quite constant. The SEM images also reveal that the skeleton consists mainly of cellulose, while lignin is most in the surrounding structure. The effects of the acid attack are apparent in the SEM observations of bagasse (Figure $2 \mathrm{a}$ $v s$ Figure 2c) and banana (Figure 2e vs Figure 2g). These micrographs show that after acid treatment, the skeleton of the fibre and its surrounding layer are partly destroyed.

While silanes cannot be directly identified by SEM, their effect on bagasse fibre morphology is substantial. Silane treatment of unpyrolyzed (Figure 3a) or pyrolyzed bagasse fibres (Figure $3 \mathrm{~b}$ ) changes the surface aspect of the fibres. After a $6 \%$ silane S1 treatment, the surface of the fibre appears rougher with striations (Figure $3 c$ and $3 d$ ), due to swelling. After treatment with a $6 \%$ silane $\mathrm{S} 2$ solution, surface texture of fibres looks "granular" (Figures 3e and $3 \mathrm{f}$ ). This can be due to silane $S_{2}$ partly covering the surface or upon drying, cracking the microfibrils surface. In addition, a densification of the fibres can also be noted in the cross-section: the hollow structure of the pyrolyzed fibres (Figure $3 b$ ) disappears after treatment with a $6 \%$ silane S1 solution (Figure 3d).

\subsubsection{Chemical composition}

After pyrolysis at $200{ }^{\circ} \mathrm{C}$, both the sugar cane bagasse and banana trunk fibres (Table 8) exhibited a decrease in the amount of extractive content, due to the elimination of volatile compounds such as methanol and acetic acid ${ }^{5,36}$. The decrease is also attributed to the easier decomposition of hemicellulose $e^{5,36}$. In the case of sugar cane bagasse, the lignin and the cellulose content increase, while for the banana trunk fibre, the lignin content decreases and the cellulose content increases. From results reported in the literature ${ }^{53,54}$, the preferential transformation of hemicelluloses is expected before that of cellulose, which precedes the transformation of lignin. Lignin decomposition begins usually while cellulose transformation is not completed. This occurs over a wide temperature range. Hence, an increase in both lignin 


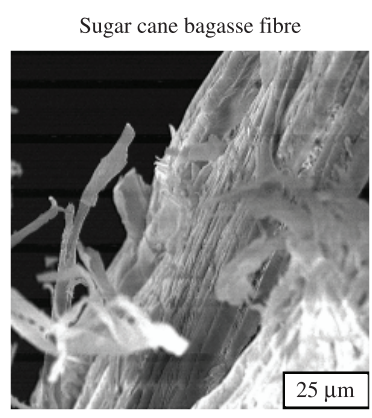

Untreated bagasse fibre $\mathrm{x} 800$

(a)

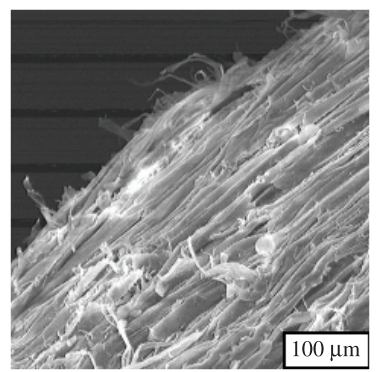

Pyrolyzed bagasse fibre x 200

(c)

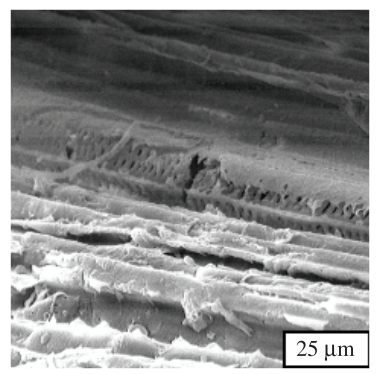

Acid treated bagasse fibre x 800

(e)

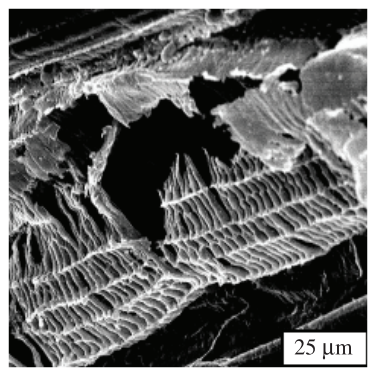

Alkali treated bagasse fibre x 800 (g)

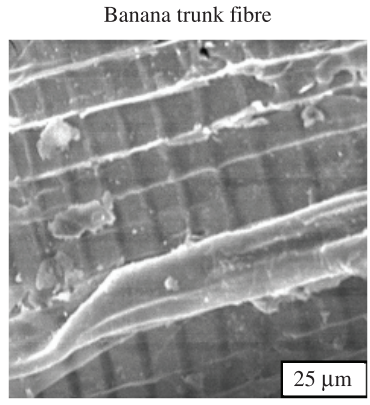

Untreated banana trunk fibre x 800

(b)

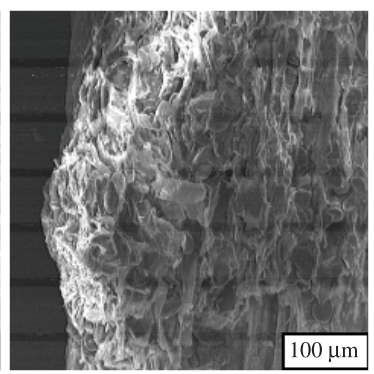

Pyrolyzed banana trunk fibre x 200

(d)

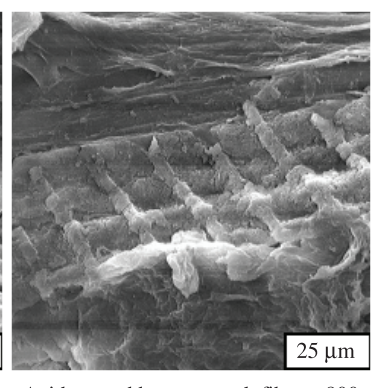

Acid treated banana trunk fibre $\mathrm{x} 800$

(f)

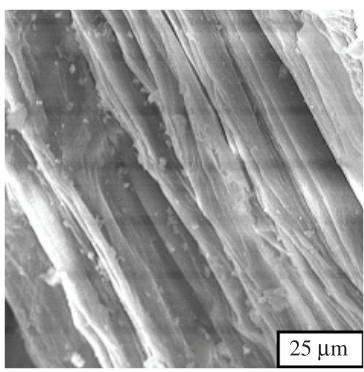

Alkali treated banana trunk fibre x 800

(h)
Figure 2. SEM images of untreated and treated bagasse and banana fibres.

and cellulose contents would be expected after pyrolysis at $200{ }^{\circ} \mathrm{C}$. It is interesting to note that the unexpected decrease in lignin content was observed in fibres in which the total amount of component was less than $100 \%$. The hydrophilic character of such fibres increases with pyrolysis. Owing to $\mathrm{OH}$ groups, the fibres fix water by forming hydrogen bonds $\mathrm{s}^{53}$.

Alkaline attack affects mostly lignin and extractives content (Table 8). It also results in a decrease in the total
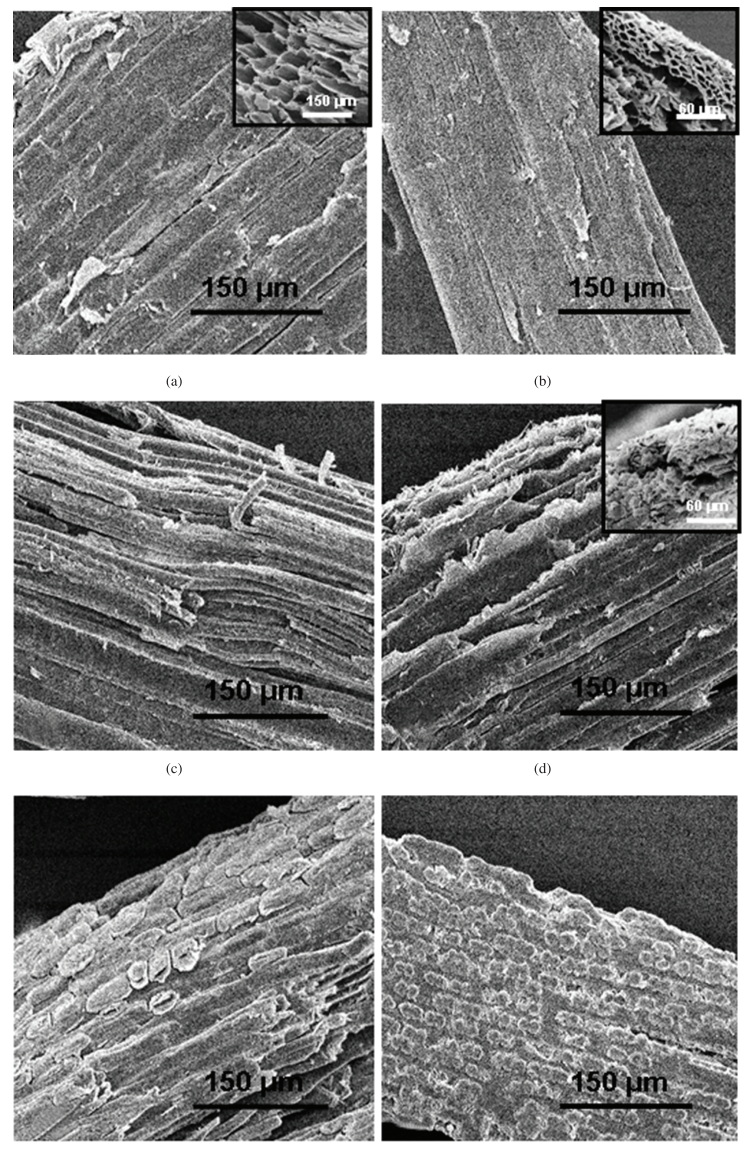

(c)

(f)

Figure 3. Scanning electron micrography of bagasse fibres a) unpyrolyzed fibre b) pyrolyzed fibre c) unpyrolyzed fibre treated with silane $\mathrm{S} 1 \mathrm{~d}$ ) pyrolyzed fibre treated with silane S1 e) unpyrolyzed fibre treated with silane S2 f) pyrolyzed fibre treated with silane S2.

fibre mass. The amount of lignin and extractives removed by alkali treatment varies with the nature of the fibre. The removed amount is greater for banana trunk than for bagasse fibres. The removal of lignin and hemicellulose, and the corresponding "enrichment" in cellulose has been shown by Sun et al. ${ }^{46}$ for wheat straw fibres. Mosier et al..$^{50}$ have also reported similar findings. In the current study, the decrease of the amount of hemicellulose obtained for bagasse fibre is consistent with prior reports ${ }^{46,50}$.

Acid treatment increases the cellulose content and strongly decreases the hemicellulose content. Such behavior is expected since attack by sulfuric acid results in the dissolution of hemicellulose and cellulose, as stated above $\mathrm{e}^{40,47}$. The increase of cellulose content, compared to their levels in raw fibre, can be explained by a preferential dissolution of the other components, and by the reaction of cellulose with sulfuric acid. Indeed, the reaction of cellulose with sulfuric acid forms an ester $\mathrm{C}_{6} \mathrm{H}_{8}\left(\mathrm{SO}_{4} \mathrm{H}\right)_{2}$ that increases the mass fraction of cellulose. The action of acid on cellulose can also entail the attack of glucosidic bonds by hydronium ions. This induces the failure of the microfibrils, and the separation of the fibre constituents. 
Table 8. Chemical composition by weight $\%$ of treated and untreated vegetable fibres.

\begin{tabular}{|c|c|c|c|c|c|c|c|c|}
\hline \multicolumn{3}{|c|}{ Fibres } & \multicolumn{4}{|c|}{ Chemical Composition in principal compounds } & \multirow[t]{2}{*}{ Water** } & \multirow{2}{*}{$\begin{array}{l}\text { Total **of } \\
\text { principal } \\
\text { compounds }\end{array}$} \\
\hline Plant & Name & Treatment & Lignin* & Extractives* & Cellulose* & Hemicellulose* & & \\
\hline \multirow{4}{*}{$\begin{array}{l}\text { Sugar cane } \\
\text { bagasse }\end{array}$} & B & ----- & 21.96 & 3.92 & 48.68 & 25.46 & 7.55 & 99.38 \\
\hline & $\mathrm{BP}$ & Pyrolysis & 23.12 & 1.88 & 49.38 & 25.62 & 12.21 & 95.79 \\
\hline & $\mathrm{BA}$ & Acid attack & 25.61 & 5.74 & 58.28 & 10.36 & 13.64 & 99.24 \\
\hline & $\mathrm{BB}$ & Alkaline attack & 19.76 & 2.75 & 59.02 & 18.46 & 5.17 & 85.31 \\
\hline \multirow{4}{*}{$\begin{array}{l}\text { Banana } \\
\text { trunk }\end{array}$} & BT & ----- & 33.46 & 11.81 & 37.97 & 16.88 & 7.76 & 82.12 \\
\hline & BTP & Pyrolysis & 30.00 & 8.34 & 45.57 & 16.08 & 11.94 & 76.98 \\
\hline & BTA & Acid attack & 27.96 & 11.88 & 53.50 & 6.65 & 24.87 & 94.99 \\
\hline & BTB & Alkaline attack & 25.55 & 1.83 & 55.42 & 17.18 & 11.86 & 62.17 \\
\hline
\end{tabular}

*weight $\%$ of principal compounds in dry fibres (hemicellulose, cellulose, lignin, extractives). **weight $\%$ of dry matter.

Table 9. Si 2p bending Energy (eV) of unpyrolyzed bagasse fibre (B), unpyrolyzed bagasse fibre treated with silane S1 (B6S1), unpyrolyzed bagasse fibre treated with silane S2 (B6S2), pyrolyzed bagasse fibre (PB), pyrolyzed bagasse fibre treated with silane S1 (PB6S1) and pyrolyzed bagasse fibre treated with silane S2 (PB6S2).

\begin{tabular}{|c|c|c|c|c|c|c|c|c|}
\hline Linkage & $\mathrm{SiC}$ & $\mathrm{SiOC}_{3}$ & $\mathrm{SiO}_{2} \mathrm{C}_{2}$ & $\mathrm{SiO}_{3} \mathrm{C}$ & $\mathrm{SiO}_{2}$ & Si-O-Si & $\mathrm{Si}(\mathrm{OR})_{\mathrm{x}}$ & $\operatorname{Si}(0)_{x}$ \\
\hline Literature & $\begin{array}{c}99.5-100.6^{(1)} \\
100.4-100.5^{(2)} \\
101^{(3)}\end{array}$ & $100.2-100.3^{(2)}$ & $101.2-101.6^{(1)}$ & $102.1-102.2^{(1)}$ & $\begin{array}{c}102.5-103 \cdot 2^{(1,2,3,4)} \\
104.4^{(5)} \\
104.7^{(2)}\end{array}$ & $102.7^{(6)}$ & $103.7^{(6)}$ & $\begin{array}{c}103.8^{(6)}(\mathrm{x}>2) \\
104.8-105^{(6)}\end{array}$ \\
\hline \multicolumn{9}{|l|}{ Sample } \\
\hline B & 100.94 & & & & 102.88 & & & \\
\hline B6S1 & 100 & & 101.66 & & 103.2 & & & \\
\hline B6S2 & & & 101.47 & & & & 103.59 & \\
\hline PB & & & 101.52 & & 103.19 & & & \\
\hline PB6S1 & 100.7 & & & 102.25 & & & & \\
\hline PB6S2 & & & & 102.07 & & & 103.43 & 105.14 \\
\hline
\end{tabular}

(1) Shimoda et al..$^{82}$, (2) Balat et al..$^{85}$, (3) Sreemany et al. ${ }^{86}$, (4) Park et al. ${ }^{84}$, (5) Ben Ali et al. ${ }^{88}$, (6) Martin et al. ${ }^{87}$.

\subsubsection{XPS analysis}

In Figure 4, XPS spectra, of unpyrolyzed fibre (Figure 4a), unpyrolyzed fibre treated by silane S1 (Figure $4 \mathrm{~b}$ ) and unpyrolyzed fibre treated by silane S2 (Figure 4c), exhibit O, C, and $\mathrm{Si}$ peaks ${ }^{81-84}$. From the experimental Si electron energy bonds (Table 9), according to various authors ${ }^{81-88}$, the following observations can be deduced:

- Mainly peaks related to $\mathrm{SiC}, \mathrm{SiO}_{2} \mathrm{C}_{2}$ and $\mathrm{SiO}_{2}$ bonds are reported on the surface;

- Peaks related to $\mathrm{Si}$ are apparently $1 \mathrm{~nm}$ underneath the surface after silane S1 or S2 treatment;

- The signature of Si $2 \mathrm{p}$ apparent at $1 \mathrm{~nm}$ below the surface, for unpyrolyzed and pyrolyzed fibres is present with low intensity. This corresponds to the inorganic elements of the fibres ${ }^{16}$.

Obviously, the presence of $\mathrm{Si}$ atoms is more evident after silane treatment. Silanes are really grafted onto the surface of the fibre, and all samples present $\mathrm{SiO}_{\mathrm{x}} \mathrm{C}_{\mathrm{y}}$ bonds due to linkages between the organic surface and the silane. The effect of pyrolysis pre-treatment is not noticeable.

\subsubsection{Porosity}

Pore size distribution, presented in Figure 5, is substantially the same for unpyrolyzed and pyrolyzed bagasse fibres. There are mainly macropores $(>0.02 \mu \mathrm{m})$ :
$97.86 \%$ for unpyrolyzed and $97.84 \%$ for pyrolyzed bagasse fibres.

The effect of pyrolysis is evident for the largest pores $(50 \mu \mathrm{m} ; 100 \mu \mathrm{m})$. They represent $15.59 \%$ for unpyrolyzed fibres and $17.26 \%$ for pyrolyzed fibres. The total porosity measured is $69.4 \%$ for unpyrolyzed fibres and $73.70 \%$ for pyrolyzed fibres. Pyrolysis causes some loss of material, which is one of the main mechanisms involved in the creation of the largest pores. The corresponding density measurement is $1.88 \mathrm{~g} / \mathrm{cm}^{3}$ for unpyrolyzed fibres and $2.03 \mathrm{~g} . \mathrm{cm}^{-3}$ for pyrolyzed fibres. The technique (helium porosity) used corresponds to "true" density of the material. It minimizes porous volume, so the total volume is reduced and the density increases inversely.

Regarding the botanical analysis, the increase in porosity $(4.27 \%)$ corresponds to the release of water and extractives that represent $4.65 \%$ of the total mass of fibres. As extractive compounds that are present vary widely, this assertion cannot be based on numerical data alone but is also supported by thermal degradation studies of the fibre observed by DSC 5 . The lighter compounds, mainly volatiles and extractives, are eliminated after the pyrolysis step. It is also possible to suggest the creation of pores that are closed or inaccessible to mercury intrusion. It is interesting to note that porosity analysis confirms previous dimensional studies. 


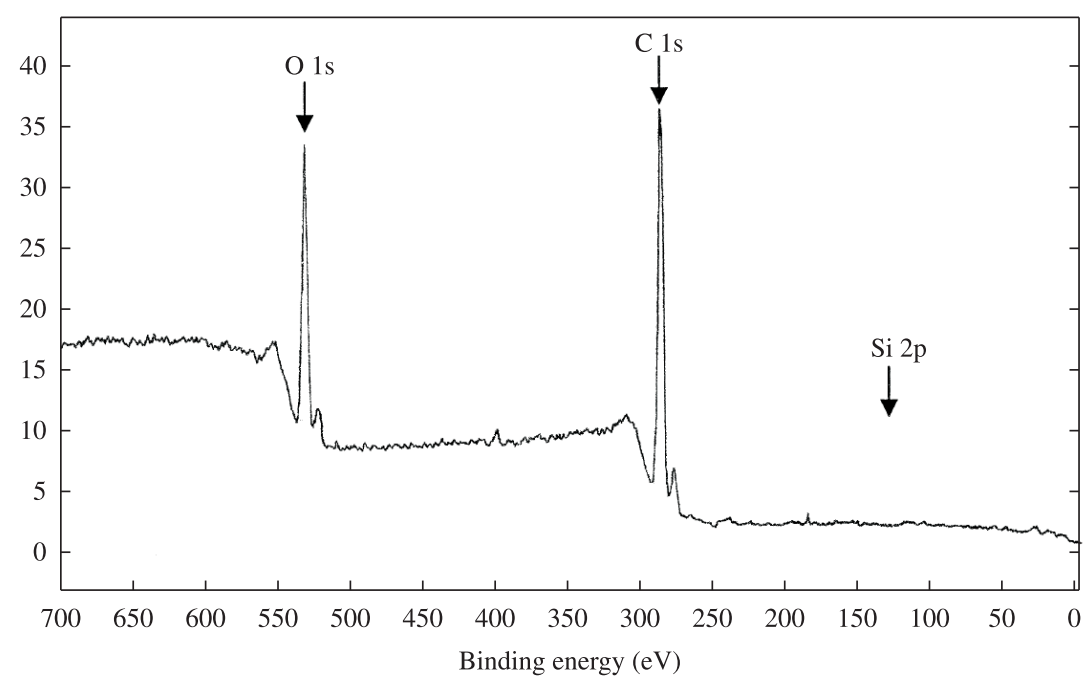

(a)

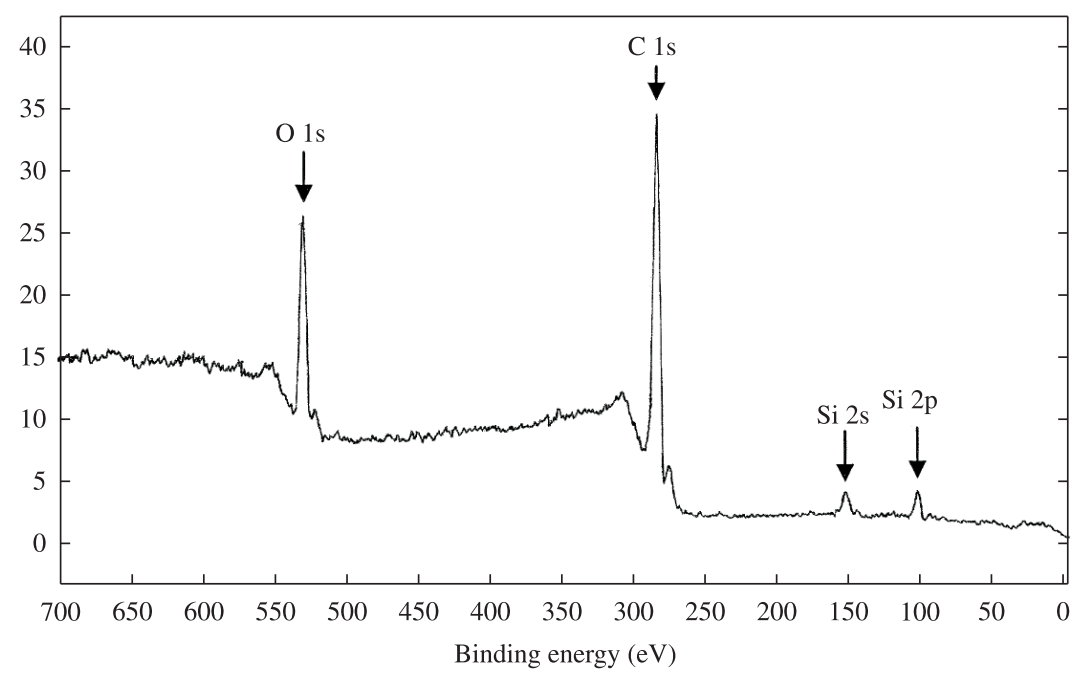

(b)

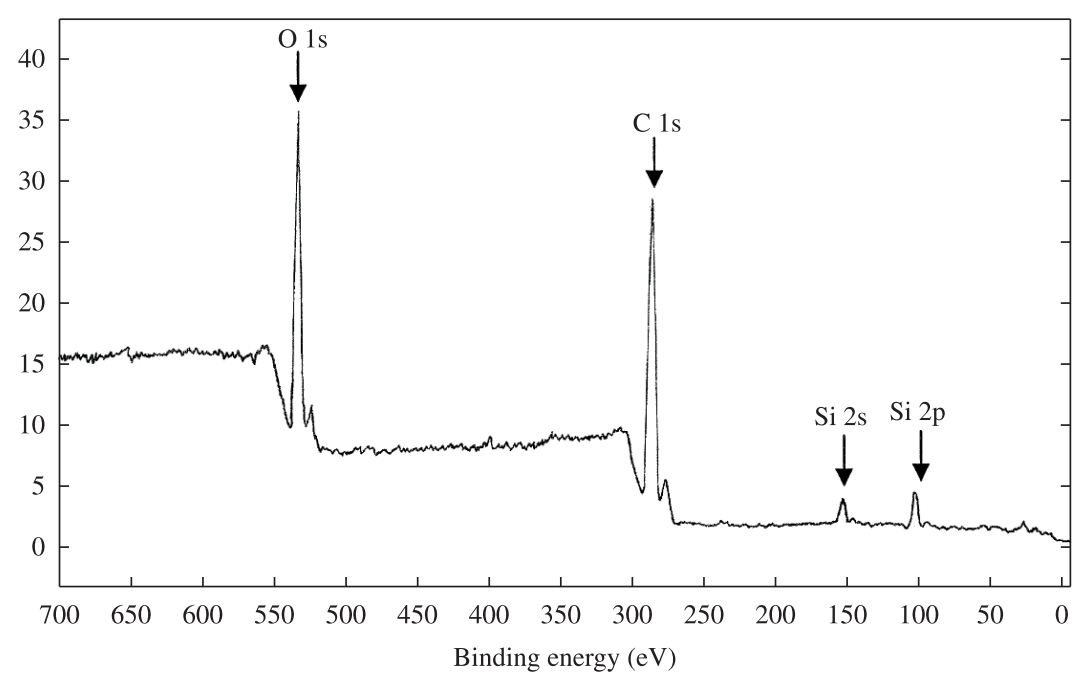

(c)

Figure 4. XPS spectra of bagasse fibres a) unpyrolyzed fibre b) unpyrolyzed fibre treated with silane S1 c) unpyrolyzed fibre treated with silane S2. 


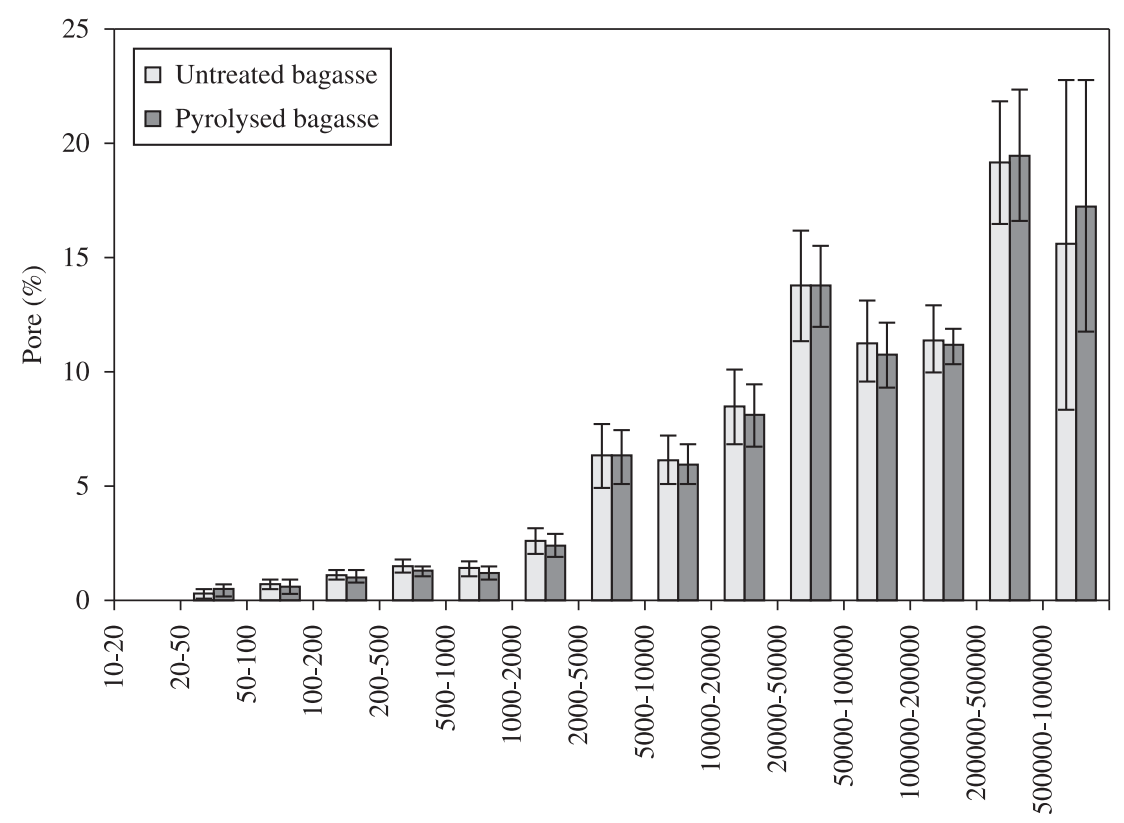

Pore radius (Angström)

Figure 5. Pore size distribution in unpyrolyzed and pyrolyzed sugar cane bagasse fibres.

For both unpyrolyzed and pyrolyzed fibres, a treatment with $6 \%$ silane enhances porosity as reported in Table 10 .

Pyrolyzed fibres, that are initially more porous than unpyrolyzed fibres, exhibit after silane treatment lower porosity than fibres only subjected to silane treatment. Raw fibres are more sensitive to the increase in porosity. Silane $\mathrm{S}_{2}$ appears to be more efficient than $S_{1}$ as regards the creation of porosity. These observations are in perfect agreement with the dimensional analysis. A hypothesis for the increase in porosity can therefore be proposed. When hydrated, the presence of water in the pore leads to the swelling of the fibres. Upon drying, water is released and silanes act as a frame that maintains pores and cell walls in their hydrated configuration, with high pore volume, even with normal humidity. Silanes are known to react with hygroscopic surface $\mathrm{OH}$ groups $^{36}$. Chemical analyses indicate that the water content also decreases after pyrolysis. Pyrolysis reduces the hydrophilic properties of the fibres, and consequently the number of $\mathrm{OH}$ groups on the surface. This decrease in $\mathrm{OH}$ groups could explain the lower sensitivity of pyrolyzed fibres treated with silanes.

\subsubsection{Water sorption}

The water uptake by the pyrolyzed, silane coated or untreated bagasse fibres has been estimated under a partial water pressure equal to $0.83 \mathrm{P}_{0}$, where $\mathrm{P}_{0}$ is the saturation vapor pressure of pure water at $35^{\circ} \mathrm{C}$ according to Greenspan ${ }^{68}$. For pyrolyzed and not pyrolyzed fibres of bagasse, silane treatment was carried out with silane $\mathrm{S}_{1}$ or $\mathrm{S}_{2}$ using silane solutions at $0.5 \%, 4 \%$ and $6 \%$.

The main observations (Figure 6) are the following:

- Fibres adsorb from 4 to $10 \%$ of their weight;

- Unpyrolyzed fibres B are more hygroscopic than pyrolyzed fibres PB;

- Water absorption is lower after silane treatment for both unpyrolyzed (B) and pyrolyzed (PB) fibres;
Table 10. Porosity and density of treated and untreated bagasse fibres.

\begin{tabular}{|c|c|c|c|c|c|c|}
\hline Fibre & B & PB & $\mathrm{BS}_{1}$ & $\mathrm{PBS}_{1}$ & $\mathrm{BS}_{2}$ & $\mathrm{PBS}_{2}$ \\
\hline $\begin{array}{l}\text { Total Porosity } \\
\text { (\%) }\end{array}$ & 69 & 74 & 87.13 & 83.39 & 91.26 & 85.69 \\
\hline $\begin{array}{l}\text { Apparent Density } \\
\left(\mathrm{g} / \mathrm{cm}^{3}\right)\end{array}$ & 0.59 & 0.65 & 0.324 & 0.539 & 0.301 & 0.489 \\
\hline
\end{tabular}

- Combination of pyrolysis and silane treatments has a sinergic effect on water sorption, the best repellent effect is then noted;

- Silane $S_{2}$ usually exhibits greater repellent effect than silane $\mathrm{S}_{1}$

- Using solutions of up to $6 \%$ silane, water absorption decreases with increasing of the silane content in the treatment solutions.

This equilibrium humidity indicates low water absorption, weight up to the equilibrium humidity.

\subsubsection{Tensile strength}

As in the case of the chemically treated fibres, the strength variations of the pyrolyzed fibres are well characterized by the lognormal distribution. The mean values associated with this distribution are presented in Figure 7 . These values clearly show that the fibre strengths increase by factors between 3 and 5 after pyrolysis treatment.

Linear correlation tests ${ }^{89}$ were used to explore the relation between fibre tensile strength and their chemical content $^{5}$. No significant correlation was established between fibre strength and lignin content. In the case of the bagasse fibres, positive correlations were obtained for humidity content (hum) and hemicellulose content (hemi). In contrast, negative correlations were obtained for cellulose content (cell) and extractive content (ext). In the case of the 


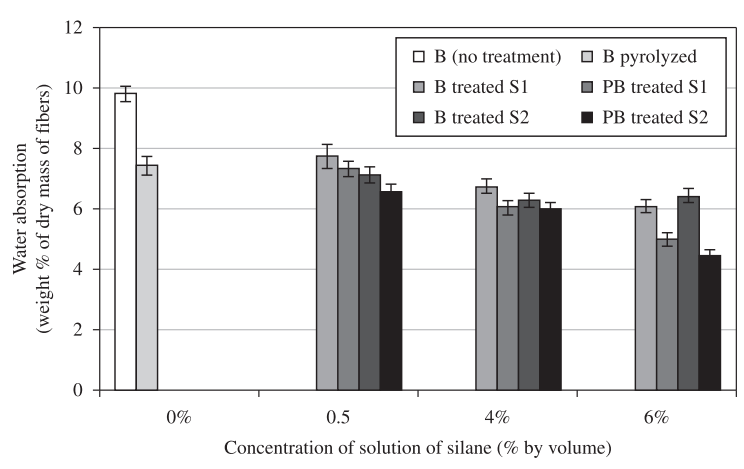

Figure 6. Water absorption of untreated and treated sugar cane bagasse fibres up to the equilibrium humidity.

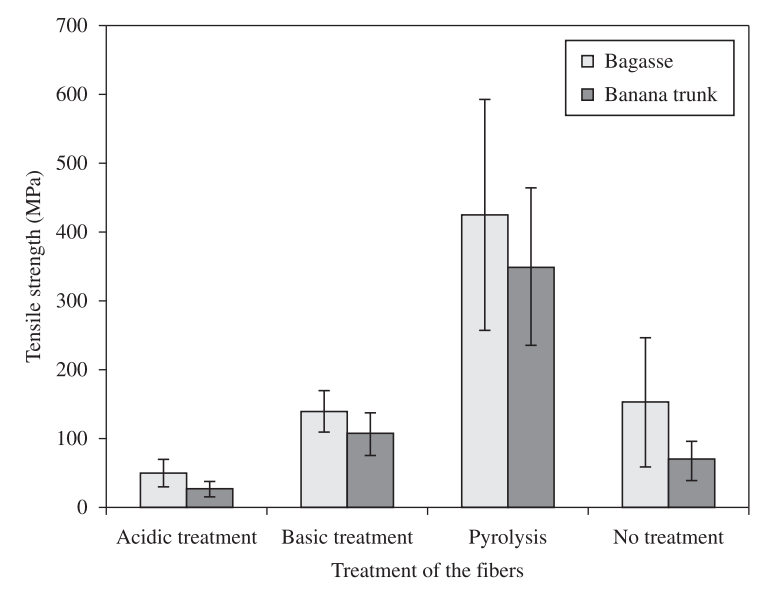

Figure 7. Tensile strength of treated and untreated fibres.

banana trunk fibre after the treatment, the significant linear correlations were only obtained for humidity and cellulose content. Also, the correlations obtained were both negative.

The SEM images (Figure 2) revealed that chemical treatment results in the dissolution of the contact zone between the unitary fibres. This destruction is partial in case of acid treatment, for which the weak contact zone and, therefore, the fibres, become weaker ${ }^{5}$. For the bagasse fibres subjected to alkali attack, the degradation of the contact zone is total, and the cellulose skeleton of the fibre is also damaged. Hence, the trends in the fibre strengths are largely attributed to the partial dissolution of the inter-wall constituents, as well as the chemical and morphological changes associated with the different treatments.

The values of the tensile strength of the pyrolyzed fibres are summarized in Table 11. The strongest pyrolyzed fibres are the bagasse, and banana leaf fibres are the weakest. Note that this is partly due to the nature of the plant and the location in the plant from which the fibres were extracted. Furthermore, a wide variability of strengths was observed between different fibres of the same species, as illustrated by the large standard deviations.

\subsection{Pulping}

\subsubsection{Pulp and fibre properties}

The by-product sisal CTMP and banana CTMP presented screened yields lower than the correspondent
Kraft pulps as can be observed in Table 6. Its behaviour is unusual and, in the present case, it should be attributed to the residual nature of the raw materials with elevated amounts of non fibrous material and due to the Somerville screen for the removal of the fines fraction.

Kappa number over 50 (Table 6) performs a crude indication of high lignin content and unfavourable conditions for submission to bleach operations related to papermaking processes (Appita P201 m-86). Damaged and fibrillated filaments are expected to present open structure and exposed lignin to undesirable attack under alkali environment.

Somerville mesh screening had positive effect on reduction of fines, defined as particles under $0.200 \mathrm{~mm}$ length with low reinforcement ability expected inside a cement brittle matrix. However, the main advantage provided by the screening was the freeness adjustment, since values less than $300 \mathrm{~mL}$ can be a problem for fibre-cement production based on Hatschek method ${ }^{66}$ during vacuum dewatering stage. Therefore pulps not submitted to Somerville (banana Kraft, commercial sisal TMP and CTMP) with low freeness are likely to be related to inconvenient stratification between fibre and cement phases, longer vacuum drainage and higher producing costs.

Average lengths of all produced fibres were considered high with effect on stronger anchorage in the matrix ${ }^{76}$. As a consequence the cement composites can present an improvement in tensile strength but also low energy absorption due to fibre fracture predominance. The aspect ratio (L/d) of fibres in all mechanical pulps was over 160 as another indication of fibre fracture during mechanical solicitation of cement based composites. Analogous study presented by Coutts ${ }^{17}$ carried on with strand sisal in OPC showed the ideal aspect ratio in the $110 \pm 50$ range for a desirable co-existence of fibre fracture and pullout. Based on this principle both sisal and banana Kraft accomplished reasonable values for the aspect ratio.

By-product sisal CTMP possessed shorter and thinner fibres than the other sisal pulps as a sign of breakage and refinement. Regardless of the damage over the filaments, the refinement is fundamental ${ }^{17}$ for fibre conformability, composite packing with consequent improvement in fibrematrix and fibre-fibre bonding.

Pulps from waste raw materials presented fibre lengthweighted average length ${ }^{78}$ with concentration of filaments up to $2.5 \mathrm{~mm}$ (Figure $8 \mathrm{a}, \mathrm{b}$ ). In the case of pulps from commercial sisal the incidence of longer particles indicated the presence of unreduced strand fibres. Such results are favourable to the mechanical pulps, cheaper and more eco-friendly than the Kraft pulps, and with very similar length distribution.

Coarseness of waste pulps was found comparable to values related to softwood and hardwood $(0.184 \mathrm{mg} / \mathrm{m}$ for Pinus radiata and $0.107 \mathrm{mg} / \mathrm{m}$ for Eucalyptus grandis as also determined in the present study) denoting thin walled filaments likely to provide acceptable spatial fibre network configuration $^{76}$.

\subsubsection{Microstructure analysis}

Figures 9a, b depict commercial sisal CTMP and TMP respectively with extensive primary wall defibrillation 
Table 11. Tensile strength of pyrolyzed fibres.

\begin{tabular}{lccccc}
\hline \multicolumn{1}{c}{ Nature of the Fibre } & Bagasse & Coconut coir & Coconut sheath & Banana trunk & Banana leaf \\
\hline Tensile strength (MPa) & 426 & 182 & 265 & 351 & 22 \\
of the fibre (mean value) & {$[ \pm 335]$} & {$[ \pm 43]$} & {$[ \pm 174]$} & {$[ \pm 227]$} & {$[ \pm 7]$} \\
Elongation at break $(\%)$ & 8.6 & 7.0 & 9.2 & 8 & n.d. \\
\hline
\end{tabular}

The standard deviation of the results is between brackets.

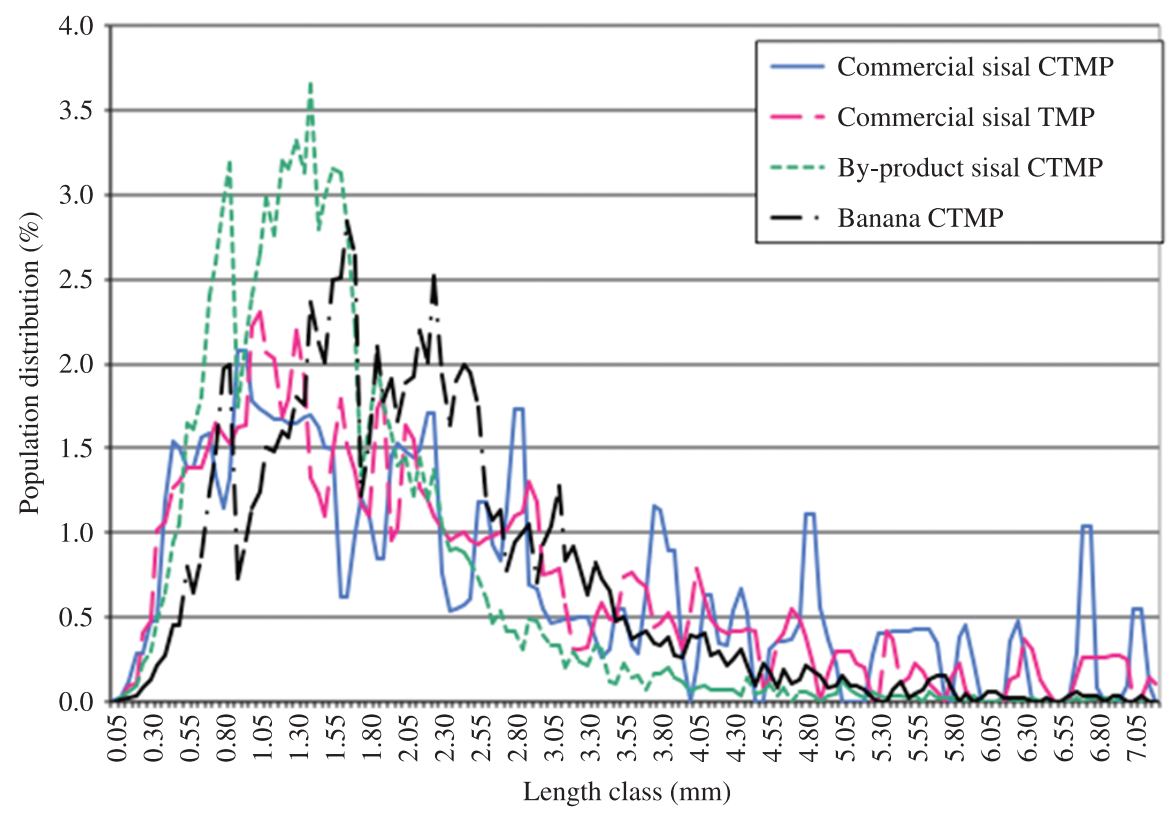

(a)

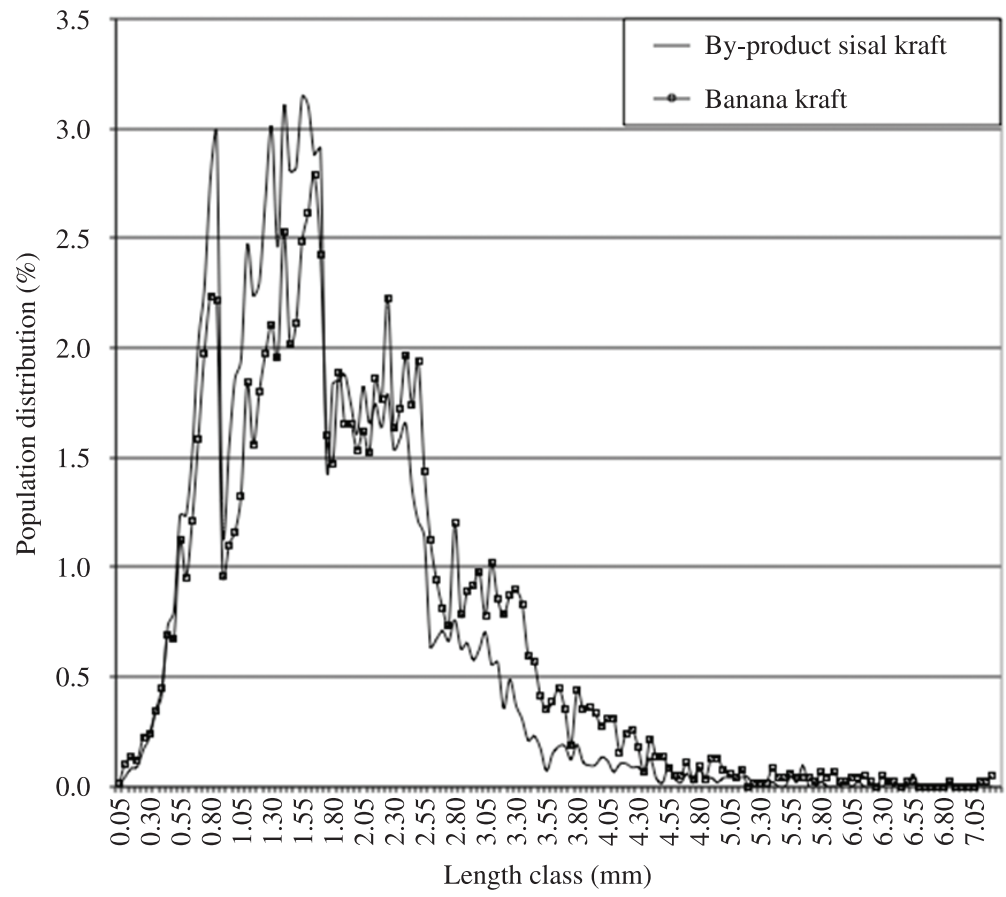

(b)

Figure 8. Pulps length-weighted length distribution: a) Mechanical pulps b) Kraft pulps. 


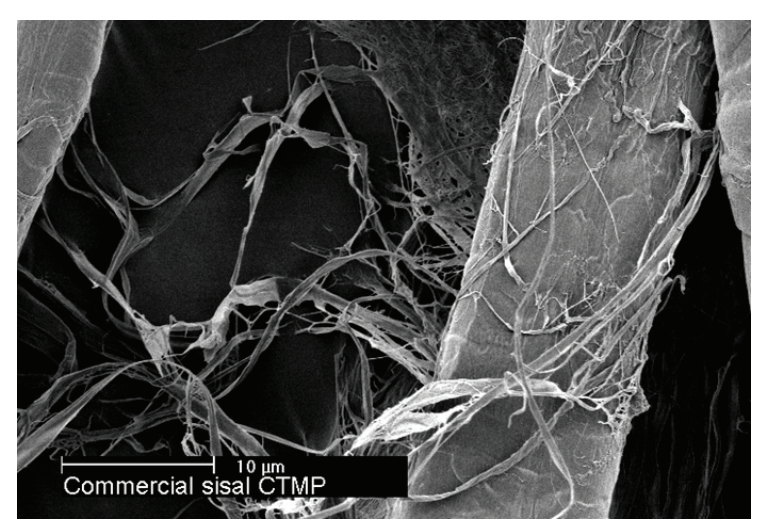

(a)

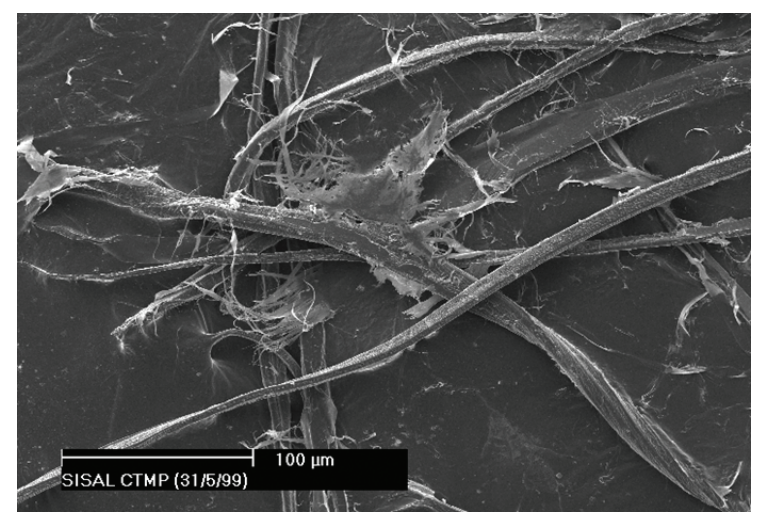

(c)

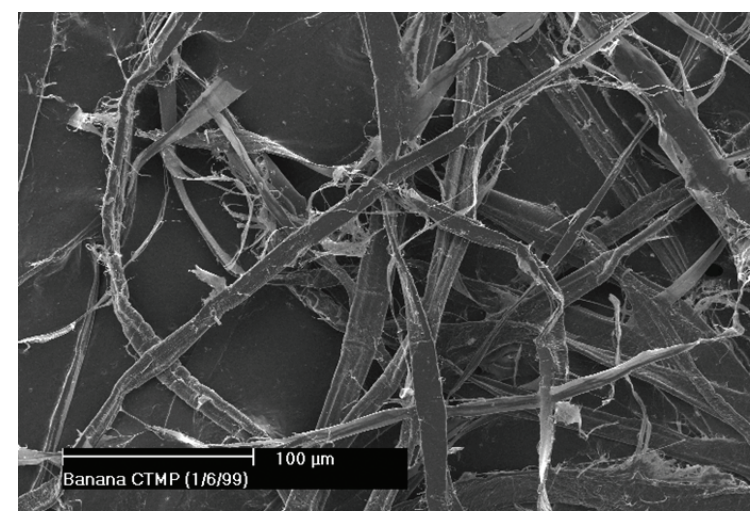

(e)

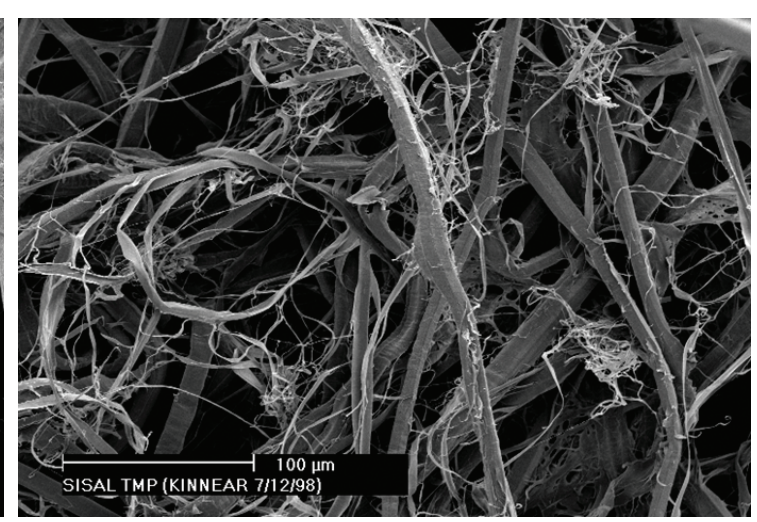

(b)

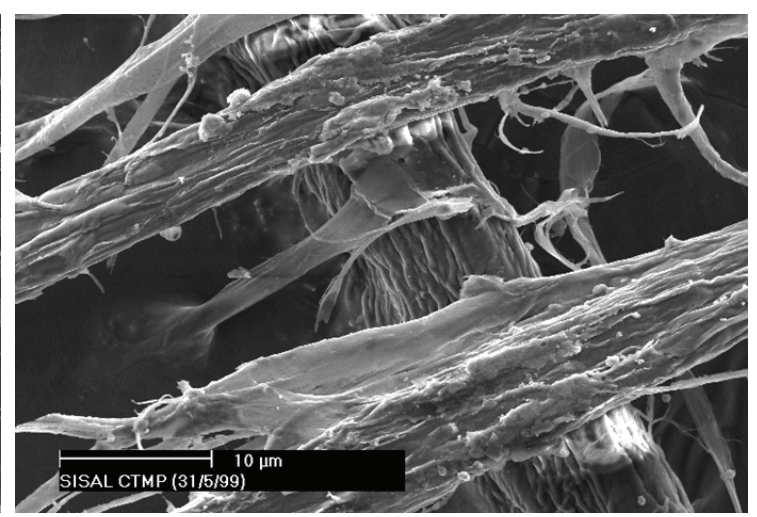

(d)

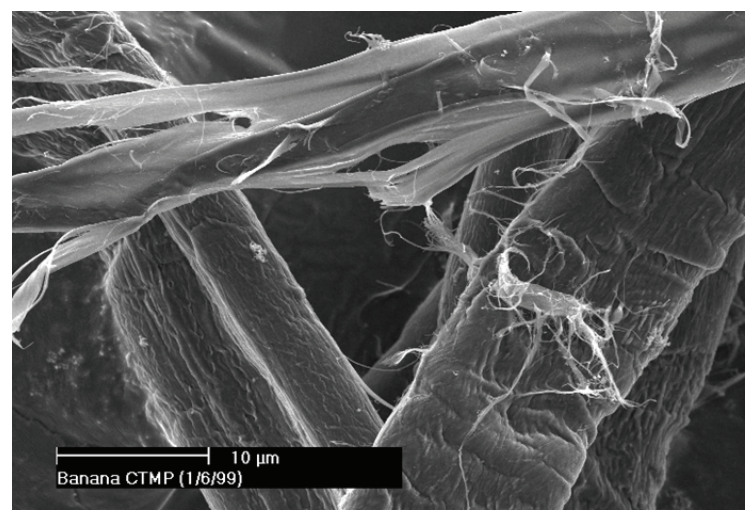

(f)

Figure 9. Detail of fibrillation of external wall: a) Commercial sisal CTMP b) Commercial sisal TMP c) By-product sisal CTMP d) By-product sisal CTMP. High magnification e) Banana CTMP f) Banana CTMP. High magnification.

regardless of stiff filaments (cell wall thickness $\sim 12.5 \mu \mathrm{m}$ as reported by Mukherjee and Satyanarayana ${ }^{90}$ in comparison to banana fibres (cell wall thickness $\sim 1.25 \mu \mathrm{m}$ ) or wood fibres (cell wall thickness $\sim 4 \mu \mathrm{m}$ ).

Figure $9 \mathrm{c}$ presents sisal by-product CTMP with evidence of mechanical reduction of the fibres as broken ends, fibrillation and twisted filaments. Some impurities from the waste raw material remained in the pulp as highlighted in Figure $9 \mathrm{~d}$ at higher magnification.

Comparison between Figures 9a and 9d makes clear the different behaviour of residual fibres providing greater incidence of refined filaments after mechanical treatment and also with surface incrustations of non-fibrous particles.

Banana CTMP (Figure 9e) showed ribbon like filaments, which corroborates with similar effect of external fibrillation for bonding improvement inside the cement matrix. Figure $9 f$ shows a broken fibre under severe damage caused by the mechanical pulping. Besides the referred mechanical treatment was likely to provide internal fibrillation and reduction of tensile strength.

As pointed out before mechanical pulps from residual sources (Figures 9c and 9e) seem to be well refined but more 
damaged and less fibrillated than commercial sisal TMP (Figure 9b) from good quality slivers. Kraft pulps from the same residual sources presented smooth and less damaged surface with possible prejudice to the cement matrix-fibre bonding ${ }^{91}$.

\section{Conclusion}

After alkaline attack the tensile strength increases slightly for banana trunk fibres and decreases slightly for sugar cane bagasse fibre, but decreases with acid attack for all the tested fibres. Pyrolysis reduces the hemicellulose and extractives content of vegetable fibres. This leads to an increase of $6 \%$ in the porosity. If the dimensions of the fibres are not modified, the surface roughness increases, which leads to the improvement of the adhesion and fibre/ matrix compatibility. Pyrolyzed fibres are less hydrophilic; they can thus potentially improve the resistance to aging of fibres and composites. Pyrolysis treatment increases tensile strength of the fibres, at least by a factor 3 .

Silanes grafted onto the fibre surface form a network of polysiloxane molecules. They change the morphology of the fibres by causing the swelling of the bagasse fibres, and they increase fibre dimensions and porosity. Silane treatment also decreases water adsorption by the fibres; this effect is more pronounced after dialkyldialkoxysilane $\left(\mathrm{S}_{2}\right)$ treatment. The effects are the same for pyrolyzed fibres. The combination of pyrolysis and silane treatments creates a lower porosity than the corresponding silane treatment alone. The hydrophilic character of the fibres strongly decreases with the cumulative contribution of both pyrolysis and silane treatments.

By-product sisal and banana strands presented good suitability for CTMP production followed by Somerville

\section{References}

1. Bilba K, Arsène MA and Ouensanga A. Materials for Construction-Comparative study of setting of various cement based composites materials. In: Proceedings of the International Ceramics Congress and 3rd Forum on New Materials; 2002; Florence, Italy. Florence; 2002.

2. Bilba K, Arsène MA and Ouensanga A. First step of valorisation of arrow roots fibres by elaboration of cementitious composites. In: Proceedings of 1 st Interamerican conference on non conventional materials and technologies in the Ecoconstruction and Infrastructure; 2003; Joao-Pessoa. JoaoPessoa; 2003.

3. Arsène MA, Bilba $\mathrm{K}$ and Ouensanga A. Etude d'un matériau composite: ciment/fibre de bagasse de canne à sucre - I. Influence des constituants de la fibre de bagasse sur la prise du matériau composite bagasse/ciment. Revue des Composites et Matériaux Avancés. 2001; 11(1):7-20. http://dx.doi. org/10.3166/rcma.11.7-20

4. De Gutiérrez RM, Diaz LN and Delvasto S. Effect of pozzolans on the performance of fibre-reinforced mortars. Cement and Concrete Composites. 2005; 27:593-598. http://dx.doi. org/10.1016/j.cemconcomp.2004.09.010

5. Arsène MA, Bilba K, Okwo AS, Soboyejo AB and Soboyejo WO. Tensile strength of vegetable fibres: effect of chemical and thermal treatments. Materials and Manufacture Processes Special Issue. 2007; 22(2):214-227. http://dx.doi. org/10.1080/10426910601063386 screening. Moderate energy costs should be projected since Asplund defibrator operated at low temperature and only three passes through Bauer refiner were required. The produced fibres are also expected to conform with requirements to fibre-cement sheets production by Hatschek related processes based on achieved freeness values between 450 and $500 \mathrm{~mL}$. Mesh screening and washing were decisive procedures, which can be attested by comparison with low freeness of unscreened banana Kraft, commercial sisal TMP and CTMP. By-product sisal and banana CTMPs presented flexible fibres regardless of more evidence of damaged filaments and impurities incrustations.

Based on the observed characteristics the pulps under evaluation obtained from by-product fibrous raw material demonstrated high potential to be used as the reinforcement of cement based composite materials.

\section{Acknowledgements}

To the CAPES-COFECUB for financial support of the collaborative project $(531 / 06)$ on "Non conventional material and technologies for civil engineering and ecoconstruction" between French and Brazilian research teams. To Prof. W. Soboyejo, from Princeton University, USA by provision of microscopy and mechanical facilities. To Dr. Robert Coutts and Mr. Peter Warden and also to Ms. A. Pereira and Mr. G. Langfors from FFP CSIRO, Australia for their skilful guidance and assistance in the pulping and characterization procedures. To Mr. J.V. Ward and Mr M. Greaves, from Ian Wark Laboratories - CSIRO, Australia by provision of microscopy facilities. To the Brazilian agencies Fapesp and $\mathrm{CNPq}$ for the financial support and scholarships provided to the Brazilian authors.

6. Tolêdo Filho RD, Ghavami K, England GL and Scrivener K. Development of vegetable fibre-mortar composites of improved durability. Cement and Concrete Composites. 2003; 25:185196. http://dx.doi.org/10.1016/S0958-9465(02)00018-5

7. Blankenhorn PR, Blankenhorn BD, Silsbee MR, DiCola $\mathrm{M}$ and Kessler K. Temperature and moisture effects on selected properties of wood fibre-cement composites. Cement and Concrete Research. 1999; 29:737-741. http://dx.doi. org/10.1016/S0008-8846(99)00046-0

8. Bledzki K and Gassan J. Composites reinforced with cellulose based fibres. Progress in Polymer Science. 1999; 24(2):221274. http://dx.doi.org/10.1016/S0079-6700(98)00018-5

9. Yue YL, Li GZ, Xu XS and Zhao ZJ. Properties and microstructures of plant-fibre-reinforced cement-based composites. Cement and Concrete Research. 2000; 30:19831986. http://dx.doi.org/10.1016/S0008-8846(00)00376-8

10. Pehanich JL, Blankenhorn PR and Silsbee MR. Wood fibre surface treatments level effects on selected mechanical properties of wood fibre-cement composites. Cement and Concrete Research. 2004; 34:59-65. http://dx.doi.org/10.1016/ S0008-8846(03)00193-5

11. Blankenhorn P, Silsbee MR, Blankenhorn BD and DiCola M. Effects of fibre surface treatments on mechanical properties of wood fibre-cement composites. Cement and Concrete Research. 2001; 31:1049-1055. http://dx.doi.org/10.1016/ S0008-8846(01)00528-2 
12. Savastano Junior H, Warden PG and Coutts RSP. Microstructure and mechanical properties of waste fibre-cement composites. Cement and Concrete Composites; 2005; 27(5):583-592. http:// dx.doi.org/10.1016/j.cemconcomp.2004.09.009

13. Coutts RSP and Warden PG. Sisal pulp reinforced cement mortar. Cement and Concrete Composites. 1992; 14:17-21. http://dx.doi.org/10.1016/0958-9465(92)90035-T

14. Coutts RSP. High yield wood pulps as reinforcement for cement products. Appita. 1986; 39(1):31-35.

15. Marikunte S and Soroushian P. Statistical evaluation of longterm durability characteristics of cellulose fibre reinforced cement composites. ACI Materials Journal. 1994; 91(6):607616.

16. Bilba K, Arsène MA and Ouensanga A. Influence of chemical treatment of vegetable fibres on insulating behavior of vegetable fibres/cement composites. In: Proceedings of Brazilian conference on non-conventional materials and technologies: Affordable housing and infrastructure; 2004; Pirassununga. Pirassununga; 2004.

17. Coutts RSP. Wood fibre reinforced cement composites. In: Swamy RN, editor. Natural Fibre Reinforced Cement and Concrete. Glasgow: Blackie; 1988. p. 1-62.

18. Onésippe C, Passecoutrin N, Toro F, Delvasto S, Bilba K and Arsène MA. Sugar cane bagasse fibres reinforced cement composites: thermal considerations. Composites Part A: Applied Sciences and Manufacturing. 2010; 44(1):549-556. http://dx.doi.org/10.1016/j.compositesa.2010.01.002

19. Savastano Junior H, Santos SF and Agopyan V. Sustainability of vegetable fibres in construction. In: Sustainability of construction materials. Cambridge: Woodhead Publishing Limited; 2009. p. 55-81. http://dx.doi.org/10.1533/9781845695842.55

20. Bilba K, Arsène MA and Ouensanga A. Study of banana and coconut fibres: botanical composition, thermal degradation and textural observations. Bioresource Technology. 2007; 68(1):5868. PMid:16442281. http://dx.doi.org/10.1016/j. biortech.2005.11.030

21. Agopyan V, Savastano Junior H, John VM and Cincotto MA. Developments on vegetable fibre-cement based materials in São Paulo, Brazil: an overview. Cement and Concrete Composites. 2005; 27:527-536. http://dx.doi.org/10.1016/j. cemconcomp.2004.09.004

22. Mathur VK. Composite materials from local resources. Construction and Building Materials. 2006; 20(7):470-477. http://dx.doi.org/10.1016/j.conbuildmat.2005.01.031

23. Tan T, Rahbar N, Allameh SM, Kwofie S, Dissmore D, Ghavami Ket al. Mechanical properties of functionally graded hierarchical bamboo structures. Acta Biomaterialia. 2011; 7(10):37963803. PMid:21704742. http://dx.doi.org/10.1016/j. actbio.2011.06.008

24. Barra B, Bergo P, Alves C, Savastano Junior H and Ghavami K. Effects of methane cold plasma in sisal fibers. Key Engineering Materials. 2012; 517:458-468. http://dx.doi.org/10.4028/www. scientific.net/KEM.517.458

25. Rabi JA, Santos SF, Tonoli GHT and Savastano Junior H. Agricultural wastes as building materials: properties, performance and applications. In: Donald NC and Jason LH, organizers. Building materials: properties, performance and applications. Hauppauge: Nova Science; 2009. p. 299-342.

26. Fournet J. Flore illustrée des phanérogames de Guadeloupe et de Martinique. expanded ed. INRA; 1978.

27. Santos F, Borem A and Caldas C, editors. Sugarcane: bioenergy, sugar and ethanol; Technology and prospects. Brasilia: Ministry of Agriculture, Livestock and Food Supply; 2012. 568 p.
28. Nolasco AM, Soffner MLAP and Nolasco AC. Physicalmechanical characterization of banana fibre, Musa cavendishii - Nanicao variety. In: Proceedings of the 2 nd International Symposium on Natural Polymers and Composites - ISNaPol98; 1998; Sao Carlos. Sao Carlos: Unesp/Embrapa/USP; 1998. p. 191-193.

29. Jarman CG, Mykoluk S, Kennedy L and Canning AJ. Banana fibre: a review of its properties and small-scale extraction and processing. Tropical Science. 1977; 19(4):173-85.

30. Andrade W, editor. Brazilian sisal. Salvador: ApexBrasil; 2006. $151 \mathrm{p}$.

31. Silva NM and Pereira AD. Experience of a pioneer - sisal - simultaneous resource for pulp and energy. Nonwood Plant Fibre Pulping Series. 1985; 15:63-69.

32. Fung KL, Xing XS, Li RKY, Tjong SC and Mai YW. An investigation on the processing of sisal fibre reinforced polypropylene composites. Composites Science and Technology. 2003; 63(9):1255-1258. http://dx.doi.org/10.1016/ S0266-3538(03)00095-2

33. Chand $\mathrm{N}$ and Jain D. Effect of sisal fibre orientation on electrical properties of sisal fibre reinforced epoxy composites. Composites Part A: Applied Science and Manufacturing. 2005; 36(5):594-602. http://dx.doi. org/10.1016/j.compositesa.2004.08.002

34. Ouensanga A. Variation of fibre composition in sugar cane stalks. Wood and fibre Science. 1989; 21:105-111.

35. Ouensanga A and Picard C. Thermal degradation of sugar cane bagasse. Thermochimica Acta. 1988; 125:89-97. http://dx.doi. org/10.1016/0040-6031(88)87213-7

36. Bilba K and Ouensanga A. Fourrier transformed infrared spectroscopic study of thermal degradation of sugar cane bagasse. Journal of Analytical and Applied Pyrolysis. 1996; 38:61-73. http://dx.doi.org/10.1016/S0165-2370(96)00952-7

37. Marquez-Montesino F, Arsène MA, Orea Igarza U, Carballo Abreu LR and Ouensanga A. Influence of tree trunk part on Char elaboration: case of Eucalyptus wood. In: Proceedings of the International Conference Carbon 2003; 2003; Oviedo, Spain. Oviedo; 2003.

38. Judt M. Non-wood plant fibres, will there be a come-back in paper-making? Industrial Crops and Products. 1993; 2:51-7. http://dx.doi.org/10.1016/0926-6690(93)90011-W

39. Lüttge U, Kluge M and Bauer G. Botanique traité fondamental. expanded ed. Tec \& Doc Press 523; 1992.

40. Sjöström E. Wood chemistry Fundamentals and applications. expanded ed. London: Academic Press; 1981.

41. Li Y, Mai YW and Ye L. Sisal fibre and its composites: a review of recent developments. Composites Science and Technology. 2000; 60:2037-2055. http://dx.doi.org/10.1016/ S0266-3538(00)00101-9

42. Smook GA. Overview of the pulp and paper industry from chemical industry. Journal of Chemical Technology and Biotechnology. 1989; 45:15-27. http://dx.doi.org/10.1002/ jctb.280450104

43. Cordeiro N, Belgacem MN, Torres IC and Moura JCVP. Chemical composition and pulping of banana trunks. Industrial Crops and Products. 2004; 19:147-154. http://dx.doi. org/10.1016/j.indcrop.2003.09.001

44. Vu TH., Pakkanen H and Alen R. Delignification of bamboo (Bambusa Pprocera acher) Part 1. Kraft pulping and the subsequent oxygen delignification to pulp with a low kappa number. Industrial Crops and Products. 2004; 19:49-57.

45. Khristova P, Kodsachia O, Patt R, Khider T and Karrar I. Alkaline pulping with additives of kenaf from Sudan. 
Industrial Crops and Products. 2002; 15:229-235. http://dx.doi. org/10.1016/S0926-6690(01)00118-2

46. Sun R, Mark Lawther J, Banks WB. Influence of alkaline pre-treatment on cell-wall components of wheat straw. Industrial Crops and Products. 1995; 4:127-145. http://dx.doi. org/10.1016/0926-6690(95)00025-8

47. Caballero JA, Marcilla A and Conesa JA. Thermogravimetric analysis of olive stones with sulphuric acid treatment. Journal of Analytical and Applied Pyrolysis. 1997; 44:75-88. http:// dx.doi.org/10.1016/S0165-2370(97)00068-5

48. Grohmann K, Cameron RG and Buslig BS. Fractionation and pretreatment of orange peel by dilute acid hydrolysis. Bioresource Technology. 1995; 54:129-141. http://dx.doi. org/10.1016/0960-8524(95)00121-2

49. Sun $Y$ and Cheng JJ. Dilute acid pretreatment of rye straw and Bermudagrass for ethanol production. Bioresource Technology. 2005; 96(14):1599-1606. PMid:15978993. http:// dx.doi.org/10.1016/j.biortech.2004.12.022

50. Mosier N, Wyman C, Dale B, Elander R, Lee YY, Holtzapple $\mathrm{M}$ et al. Features of promising technologies for pretreatment of lignocellulosic biomass. Bioresource Technology. 2005; 96:673-686. PMid:15588770. http://dx.doi. org/10.1016/j.biortech.2004.06.025

51. Araki J, Wada M, Kuga S and Okano T. Flow properties of microcristalline cellulose suspension prepared by acid treatment of native cellulose. Colloids and Surfaces A: Physicochemical and Engineering Aspects. 1998; 142:75-82. http://dx.doi.org/10.1016/S0927-7757(98)00404-X

52. Pouteau C, Cathala B, Dole P, Kurek B and Monties B. Structural modification of Kraft lignin after acid treatment: characterisation of the apolar extracts and influence on the antioxidant properties in polypropylene. Industrial Crops and Products. 2005; 21:101-108. http://dx.doi.org/10.1016/j. indcrop.2004.01.003

53. Shafizadeh F. Introduction to pyrolysis of biomass. Journal of Analytical and Applied Pyrolysis. 1982; 3:283-305. http:// dx.doi.org/10.1016/0165-2370(82)80017-X

54. Marcilla A, Conesa JA, Asensio M and Garcia-Garcia SM. Thermal treatment and foaming of chars obtained from almond shells: kinetic study. Fuel. 2000; 79:829-836. http://dx.doi. org/10.1016/S0016-2361(99)00206-9

55. Várhegi G, Antal Junior MJ, Jakab E and Szabó P. Kinetic modelling of biomass pyrolysis. Journal of Analytical and Applied Pyrolysis. 1997; 42:73-87. http://dx.doi.org/10.1016/ S0165-2370(96)00971-0

56. Capart R, Khezami L and Burnham AK. Assessment of various kinetic models for the pyrolysis of microgranular cellulose. Thermochimica Acta. 2004; 417:79-89. http://dx.doi. org/10.1016/j.tca.2004.01.029

57. Tsujiyama $\mathrm{T}$ and Miyamori A. Assignment of DSC thermograms of wood and its components. Thermochimica Acta. 2000; 351:177-181. http://dx.doi.org/10.1016/S00406031(00)00429-9

58. Paris O, Zollfrank $\mathrm{C}$ and Zickler GA. Decomposition and carbonisation of wood biopolymers-a microstructural study of softwood pyrolysis. Carbon. 2005; 43:53-66. http://dx.doi. org/10.1016/j.carbon.2004.08.034

59. Abou-Yousef H, El-Sakhawy M and Kamel S. Multistage pulping by using alkali/cairo's acid treatment. Industrial Crops and Products. 2004; 21(3):337-341. http://dx.doi.org/10.1016/j. indcrop.2004.05.001

60. Garrote G, Eugenio ME, Díaz MJ, Ariza J and López F. Hydrothermal and Pulp processing of Eucalyptus. Bioresource
Technology. 2003; 88:61-68. http://dx.doi.org/10.1016/S09608524(02)00256-0

61. Pothan LA and Thomas S. Polarity parameters and dynamic mechanical behaviour of chemically modified banana fibre reinforced polyester composites. Composites Science and Technology. 2003; 63:1231-1240. http://dx.doi.org/10.1016/ S0266-3538(03)00092-7

62. Coutinho FB, Costa THS, Carvalho DL, Gorelova MM and De Santa Maria JC. Thermal behaviour of modified wood fibres. Polymer Testing. 1998; 17:299-310. http://dx.doi.org/10.1016/ S0142-9418(97)00059-7

63. Ausnewz. Price watch: pulp,paper and board. Hobart. 1999; 13(4):11.

64. Bhargava GG, Joshi RC, Alok K, Maheshwari GD, Mishra BP and Mishra RP. Evaluation of sisal (Agave cantala) and sisal hemp (Agave sisalana) for paper making. Ippta. 1991; 3(2):7682.

65. Murthy NVSR, Vidya Sagar CHV and Rudrayya G. Pulping of Agave sisalana. Ippta. 1991; 3(4):50-54.

66. Coutts RSP and Ridikas V. Refined wood fibre-cement products. Appita. 1982; 35(5):395-400.

67. Higgins HG. Paper physics in Australia. Melbourne: CSIRO Division of Forestry and Forest Products; 1996.

68. Greenspan L. Humidity fixed points of binary saturated aqueous solutions. Journal of Research of the National Bureau of Standards - A Physics and Chemistry. 1977; 81A(1):89-96.

69. Ramos J, Davalos F and Navarro F. High yield pulping from sugar cane bagasse and other non wood plant fibres, an state of the art review. In: Proceedings of the Nanjing International Symposium on High Yield Pulping; 1997; Nanjing. Nanjing: Chinese Academy of Forestry; 1997. p. 152186. PMid:9580238.

70. Higgins HG, Irvine GM, Puri V and Wardrop AB. Conditions for obtaining optimum properties of radiata and slash pine thermomechanical and chemitermomechanical pulps. Appita. 1978; 32(1):23-33.

71. Clark NB. The pulpwood quality of trees grown in the MurrayDarling Basin. [Dissertation]. Melbourne University; 1998.

72. Irvine GM. Chemical and paper laboratory course: chemical pulping. Melbourne: Monash University/CSIRO-FFP; 1995. p. 1-17.

73. Zhu WH. Utilisation of banana fibre in composite materials. Melbourne: Victoria University of Technology; 1993.

74. Fernandes JD, Unkalkar VG, Meshramkar PM, Jaspal NS and Didwania HP. Pulping and papermaking of banana (Musa cavendishii) plants. Nonwood Plant Fibre Pulping Series. 1981; 11:73-89.

75. Misra DK. Pulping and bleaching of nonwood fibres. In: Casey JP. Pulp and paper: chemistry and chemical technology. 3rd ed. Wiley; 1983. p. 504-530.

76. McKenzie AW. A guide to pulp evaluation. Melbourne: CSIRO; 1994.

77. Carvalho MG, Ferreira PJ, Martins AA and Figueiredo MM. A comparative study of two automated techniques for measuring fibre length. Tappi Journal. 1997; 80(2):137-42.

78. Bichard W and Scudamore P. An evaluation of the comparative performance of the Kajaani FS-100 and FS-200 fibre length analyzers. Tappi Journal. 1988; 71(12):149-55.

79. Arsène MA. Elaboration et caractérisation de matériauxCas de conducteurs et de matériaux issus de sous-produits lignocellulosiques tropicaux. Guadeloupe; 2006. HDR thesis.

80. Bilba K. Elaboration et caractérisation de matériaux composites. Guadeloupe; 2006.HDR thesis. 
81. Valadez-Gonzalez A, Cervantes-Uc JM, Olayo R and Herrera-Franco PJ. Chemical modification of henequen fibres with an organosilane coupling agent. Composites Part B: Engineering. 1999; 30:321-331. http://dx.doi.org/10.1016/ S1359-8368(98)00055-9

82. Shimoda K, Park JS, Hinoki T and Kohyama A. Influence of $\mathrm{SiC}$ nano-sized powder analyzed by X-ray photoelectron spectroscopy on basic powder characteristics. Applied Surface Science. 2007; 253:9450-9456. http://dx.doi.org/10.1016/j. apsusc.2007.06.023

83. Tserki V, Zafeiropoulos NE, Simon F and Panayiotou C. A study of the effect of acetylation and propionylation surface treatments on natural fibres. Composites Part A: Applied Science and Manufacturing. 2005; 36:1110-1118. http://dx.doi. org/10.1016/j.compositesa.2005.01.004

84. Park BD, Wi SG, Lee KH, Singh AP, Yoon TH and Kim YS. X-ray photoelectron spectroscopy of rice husk surface modified with maleated polypropylene and silane. Biomass and Bioenergy. 2004; 27:353-363. http://dx.doi.org/10.1016/j. biombioe.2004.03.006

85. Balat M, Berjoan R, Pichelin G and Rochman D. Hightemperature oxidation of sintered silicon carbide under pure $\mathrm{CO}_{2}$ at low pressure: active-passive transition. Applied Surface Science. 1998; 133:115-123. http://dx.doi.org/10.1016/S01694332(98)00193-7
86. Sreemany M, Ghosh TB, Pai BC and Chakraborty M. XPS Studies on the oxidation behaviour of $\mathrm{SiC}$ particles. Materials Research Bulletin. 1998; 33(2):189-198. http://dx.doi. org/10.1016/S0025-5408(97)00222-5

87. Martin HJ, Schulz KH, Bumgardner JD and Walters KB. An XPS study on the attachement of triethoxsilylbutyraldehyde to two titanium surfaces as a way to bond chitosan. Applied Surface Science. 2008; 254(15):4599-4605. http://dx.doi. org/10.1016/j.apsusc.2008.01.066

88. Ben Ali M, Bessueille F, Chovelon JM, Abdelghami A, Jaffrezic-Renault N, Maaref MA and Martelet C. Use of ultrathin organic silane films for the improvement of gold adhesion to the silicon dioxide wafers for (bio)sensor applications. Materials Science and Engineering. 2008; C 28(5-6):628-632.

89. Harper WM. Statistics. 6th ed. ELSB; 1992.

90. Mukherjee PS and Satyanarayana KG. Structure and properties of some vegetable fibres. Part 1 sisal fibre. Journal of Materials Science. 1984; 19:3925-3934. http://dx.doi.org/10.1007/ BF00980755

91. Savastano Junior H, Warden PG and Coutts RSP. Evaluation of pulps from natural fibrous material for use as a reinforcement in cement product. Materials and Manufacturing Processes. 2004; 19(5):963-978. http://dx.doi.org/10.1081/ AMP-200030684 